\title{
Genetic Engineering of Phenylpropanoid Pathway in Leucaena leucocephala
}

\author{
Bashir M. Khan ${ }^{*}$ \\ National Chemical Laboratory (NCL) \\ India
}

\section{Introduction}

Trees are reservoirs of many economically and biotechnologically significant products. Wood, one such gifts of nature, consists of lignin, hemicelluloses, and cellulose. Biochemistry of lignin, which being one of the most abundant biopolymers on earth, has been studied extensively, partly due to the significance, and interest of such knowledge from industrial point of view (Boerjan et al., 2003). Lignin has far reaching impacts on agriculture, industry and the environment, making phenylpropanoid metabolism, a major route for synthesis of lignin in plants, a globally important part of plant chemistry.

Besides its critical role in normal plant health and development, high levels of lignin are problematic in the agro-industrial exploitation of various plant species. It is considered an undesirable component in paper manufacture due to the cost, energy consumption, and pollutant generating processes required for its removal (Baucher et al., 2003; Boerjan, 2005; Chiang, 2002). Thus, making it essential to provide designer plant species with altered lignin content, and hence, to diminish the pressure on the domestication of natural forest resources in the future. Considerable scientific interest has been focused on the development of trees with improved wood quality through modification of different genes involved in lignin biosynthesis, which could be important for the improved end use of wood material (Chiang, 2006; Higuchi, 2006). Leucaena leucocephala, one of the most versatile fast growing commercially important trees for paper and pulp industry in India, contributes nearly a quarter of the total raw material. The wider use of this tree species in the pulp industry is due to its high rate of biomass production and ability to adapt to a variety of soils and climatic conditions. Every step towards the development of this tree variety in terms of increased biomass and reduced lignin content would be of great help to pulp and paper industry as it will decrease cost and release of hazardous chemicals during the production of paper pulp.

This chapter will briefly cover, the chemistry of lignin deposition in plants, role of different monolignol biosynthesis pathway genes, followed by studies concentrated on genetic

\footnotetext{
* Shuban K. Rawal ${ }^{2}$, Manish Arha ${ }^{1}$, Sushim K. Gupta ${ }^{1}$, Sameer Srivastava ${ }^{1}$, Noor M. Shaik ${ }^{1}$, Arun K. Yadav $^{1}$, Pallavi S. Kulkarni ${ }^{1}$, O. U. Abhilash ${ }^{1}$, SantoshKumar ${ }^{1}$, Sumita Omer ${ }^{1}$, Rishi K. Vishwakarma ${ }^{1}$, Somesh Singh', R. J. Santosh Kumar ${ }^{1}$, Prashant Sonawane. ${ }^{1}$, Parth Patel ${ }^{1}$, C. Kannan ${ }^{1}$, Shakeel Abbassi ${ }^{1}$ ${ }^{1}$ National Chemical Laboratory (NCL), ${ }^{2}$ Ajeet Seeds Pvt. Ltd.
} 
engineering of phenylpropanoid pathway in Leucaena leucocephala as tool for altering its lignin composition, thereby its application in pulp and paper industries.

\section{Lignin: Occurrence, structure and function}

Lignin (from Latin lignum meaning wood), is one of the most abundant natural organic polymer next only to cellulose (Boerjan et al., 2003). It is a vital cell wall component of all vascular plants and represents on an average of $25 \%$ of the terrestrial biomass. It plays crucial role in structural integrity of cell wall \& stiffness and strength of stem (Chabannes et al., 2001; Jones et al., 2001). Lignin is primarily synthesized and deposited in the secondary cell wall of specialized cells such as xylem vessels, tracheids and fibers. It is also deposited in minor amounts in the periderm where association with suberin provides a protective role against pathogens. In addition, lignin waterproofs the cell wall; enabling transport of water and solutes through the vascular system (Sarkanen \& Ludwig, 1971). Lignins are complex racemic aromatic heteropolymers synthesized from the dehydrogenative polymerization of monolignols, namely coumaryl, coniferyl and sinapyl alcohol monomers differing in their degree of methoxylation (Freudenberg \& Neish, 1968). These monolignols produce respectively, p-hydroxyphenyl $(\mathrm{H})$, guaiacyl $(\mathrm{G})$ and syringyl $(\mathrm{S})$ phenylpropanoid units when incorporated into the lignin polymer (Fig. 1). The amount and composition of lignins vary among taxa, cell types and individual cell wall layer, and are influenced by developmental and environmental cues (Campbell \& Sederoff, 1996). Lignin content is higher in softwoods (27-33\%) than in hardwood (18-25\%) and grasses (17-24\%). The highest amounts of lignin (35-40\%) occur in compression wood on the lower part of branches and leaning stems (Sarkanen \& Ludwig, 1971).

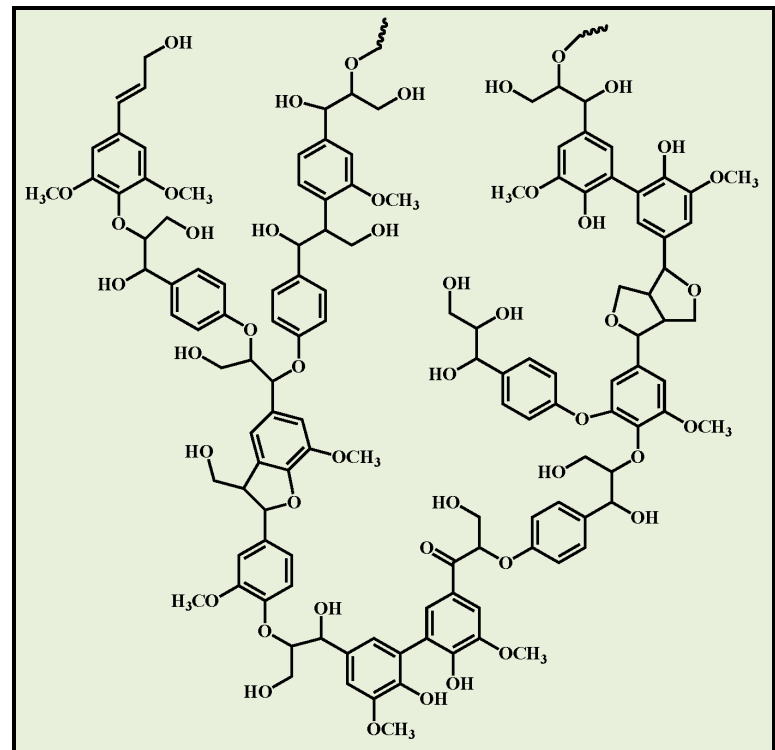

Fig. 1. Structure of a lignin oligomer. These structures consist of phenylpropanoid units $\mathrm{H}$, $\mathrm{G}$ and S. A number of such oligomers cross-polymerizes to form a complex structure of lignin 


\subsection{Lignin biosynthesis}

Although lignin has been studied for over a century, many aspects of its biosynthesis still remain unresolved. The monolignol biosynthetic pathway has been redrawn many times, yet still remains a matter of debate. During the last two decades, significant headway has been made in isolating and characterizing a number of genes pertaining to monolignol biosynthesis from different plants. Several reviews on the advancements of monolignol biosynthesis pathways are also available (Boerjan et al., 2003; Humphreys \& Chapple, 2002; Whetten \& Sederoff, 1995; Whetten et al., 1998).

In plants, lignins are synthesized by the polymerization of monolignols, namely p-coumaryl, coniferyl and sinapyl alcohol monomers differing in their degree of methoxylation (Higuchi, 1985; Sederoff \& Chang, 1991) via phenylpropanoid biosynthetic pathway (Gross, 1985). This pathway comprises a complex series of branching biochemical reactions responsible for synthesis of a variety of products like lignin, flavonoids and hydroxycinnamic acid conjugates. Many intermediates and end products of this pathway play important role in plant such as phytoalexins, antiherbivory compounds, antioxidants, ultra violet (UV) protectants, pigments and aroma compounds. Finally, the diverse functions of lignin and related products in resistance to biotic and abiotic stresses make this pathway vital to the health and survival of plants.

The synthesis of lignin represents one of the most energy demanding biosynthetic pathways in plants, requiring large quantities of carbon skeletons. Deposition of lignin in plants proceeds via the following steps:

1. The biosynthesis of monolignols

2. Transport of monolignols from the site of synthesis to the site of polymerization

3. Dehydrogenation \& Polymerization of monolignols.

\subsubsection{Biosynthesis of monolignols}

The biosynthesis of monolignols proceeds through the phenylpropanoid pathway starting with deamination of phenylalanine to produce cinnamic acid and involves successive hydroxylation reactions of the aromatic ring, followed by phenolic o-methylation and conversion of the side chain carboxyl to an alcohol group (Fig. 2). Immense amount of work has been done in characterizing the monolignol biosynthesis pathway in past two decades. It is a complex pathway comprising of enzymes with functions like methyltransferase, hydroxylase, reductase and dehydrogenase. Some of the important enzymes involved in monolignol biosynthesis have been discussed below.

\subsubsection{Phenylalanine ammonia-lyase (PAL)}

The enzyme phenylalanine ammonia-lyase (PAL; EC: 4.3.1.5) that catalyzes the conversion of phenylalanine to transcinnamic acid, is the initial step towards monolignol biosynthesis and other phenolic secondary plant metabolites. Genes encoding PAL have been studied in Populus species (Kao et al. 2002; Osakabe et al., 1995), loblolly pine and other plant species (Bate et al., 1994; Hatton et al., 1995; Jones, 1984; Kumar \& Ellis, 2001; Leyva et al., 1992; Ohl et al., 1990). PAL exists as a multiple member gene family and the individual members can be involved in different metabolic pathways as suggested by their expression patterns in association with certain secondary compounds accumulated in specific tissue or 


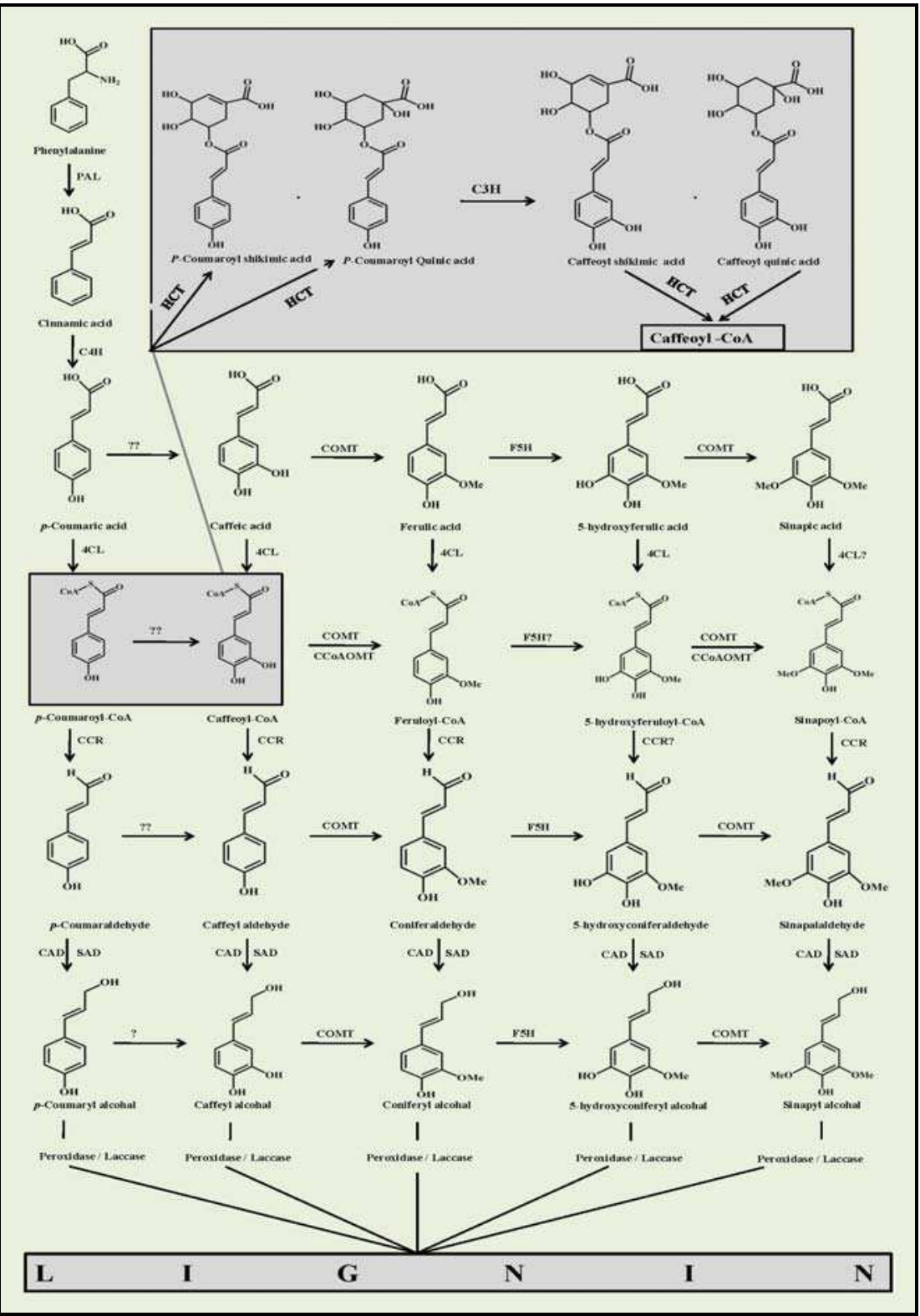

Fig. 2. An overview of monolignol biosynthesis pathway: PAL, Phenylalanine ammonialyase; $\mathrm{C} 4 \mathrm{H}$, Cinnamic acid 4-hydroxylase; $\mathrm{C} 3 \mathrm{H}$, p-Coumarate 3-hydroxylase; $\mathrm{HCT}$, Hydroxycinnamoyltransferase; 4CL, 4-Coumarate-CoA ligase; CCoAOMT, Caffeoyl-CoA Omethyltransferase; CCR, Cinnamoyl CoA reductase; CAld5H, Coniferyl aldehyde 5hydroxylase; AldOMT, 5- hydroxyconiferyl aldehyde O-methyltransferase; CAD, Cinnamyl alcohol dehydrogenase; SAD, Sinapyl alcohol dehydrogenase 
developmental stage. The biochemical activity of all known PALs is verified as specific deamination of phenylalanine, but genetic and physiological function may vary among different PAL members. The expression of PAL genetic function is controlled by various genetic circuits and signaling pathways.

\subsubsection{Cinnamate 4-Hydroxylase $(\mathrm{C} 4 \mathrm{H})$}

C4H (EC: 1.14.13.11) constitutes the CYP73 family of the large group of Cyt P450 monooxygenases. It catalyzes the 4-hydroxylation of trans-cinnamate, the central step in the generation of phenylalanine-derived substrates for the many branches of phenylpropanoid metabolism. The first and the last enzymes of this short sequence of closely related reactions, termed the general phenylpropanoid metabolism, are PAL and 4CL, respectively. A second metabolic link couples $\mathrm{C} 4 \mathrm{H}$ to the membrane-localized Cyt P450 Reductase (CPR). The expression patterns of all three $\mathrm{C} 4 \mathrm{H}$-linked enzymes, PAL, 4CL, and $\mathrm{CPR}$, and of the corresponding mRNAs have been analyzed in cell-suspension cultures and various intact tissues of parsley (Logemann et al., 1995) and Arabidopsis (Mizutani and Ohta, 1997). A reduction in PAL levels leads to an increase in the $\mathrm{S} / \mathrm{G}$ ratio, whereas reduced $\mathrm{C} 4 \mathrm{H}$ activity leads to a decrease in the $S / G$ ratio. These observations support the existence of some sort of metabolic channeling between the enzymes of the central phenylpropanoid pathway and those of monolignol biosynthesis and also provide a basis for the development of new strategies for modified or reduced lignin content.

Similar to PAL, $\mathrm{C} 4 \mathrm{H}$ is thought to be involved in a number of secondary metabolism pathways in addition to monolignol biosynthesis as $p$-coumarate is an intermediate for biosynthesis of many secondary compounds (Croteau et al., 2000). Multiple C4H gene members are identified in many plant species, however, only one $\mathrm{C} 4 \mathrm{H}$ is known in the Arabidopsis genome (Raes et al., 2003). The expression study of two $\mathrm{C} 4 \mathrm{H}$ members in quaking aspen indicated that one is strongly expressed in developing xylem tissues and the other is more active in leaf and young shoot tissues (Shanfa et al., 2006). In other species, $\mathrm{C} 4 \mathrm{H}$ gene is expressed in a variety of tissues and the expression is induced by wounding, light, pathogen attacks and other biotic \& abiotic stimuli (Bell-Lelong et al., 1997; Raes et al., 2003). The mechanisms that regulate the genetic function of $\mathrm{C} 4 \mathrm{H}$ gene and its family members are yet unknown.

\subsubsection{Coumarate 3-hydroxylase $(\mathrm{C} 3 \mathrm{H})$}

Early biochemical evidence suggested that conversion of coumarate to caffeate is catalyzed by a nonspecific phenolase, but that suggestion did not receive much support in other studies (Boniwell \& Butt, 1986; Kojima \& Takeuchi, 1989; Petersen et al., 1999; Stafford \& Dresler, 1972). The gene encoding $p$-coumarate 3-hydroxylase $(\mathrm{C} 3 H)$ was cloned and an alternative pathway proposed based on the enzyme activity of CYP98A3 gene from Arabidopsis (Franke et al., 2002 a; Nair et al., 2002; Schoch et al., 2001).

\subsubsection{4 p-hydroxycinnamoyl-CoA: quinate shikimate p-hydroxycinnamoyl- transferase (HCT)}

The enzyme $p$-coumarate 3-hydroxylase $(\mathrm{C} 3 \mathrm{H})$ converts $p$-coumaric acid into caffeic acid and has been shown to be a cytochrome p450-depenedent monooxygenase. It is interesting to note that enzymatic assays have demonstrated that the shikimate and quinate esters of $p$-coumaric acid are the preferred substrates for $\mathrm{C} 3 \mathrm{H}$ over $p$-coumaric acid, $p$-coumaroyl-CoA, $p$ coumaraldehyde, $p$-coumaryl alcohol, nor the 1-O-glucose ester and 
the 4-O-glucoside of $p$-coumaric acid are good substrates (Franke et al., 2002; Nair et al., 2002; Schoch et al., 2001). $p$-Coumarate is first converted to $p$-coumaroyl-CoA by 4CL, with subsequent conversion to $p$-coumaroyl-shikimate and $p$-coumaroyl-quinate, the substrates for $\mathrm{C} 3 \mathrm{H}$, by $p$-hydroxycinnamoyl-CoA:quinate-(CQT) or $p$-hydroxycinnamoyl-CoA:shikimate $p$-hydroxycinnamoyltransferase (CST) (Schoch et al., 2001). These enzymes, described as reversible enzymes, can convert caffeoyl-shikimate or caffeoyl-quinate (chlorogenic acid) into caffeoyl-CoA, the substrate for CCoAOMT. A reversible acyltransferase with both CQT and CST activity, designated HCT, has been purified and the corresponding gene cloned from tobacco (Hoffmann et al., 2002). Silencing of HCT through RNA interference (RNAi) lead to reduction in lignin, hyper accumulation of flavonoids and growth inhibition in Arabidopsis (Chapple, 2010; Hoffmann et al., 2004, 2007)

\subsubsection{Coumarate Coenzyme-A ligase (4CL)}

Genetic and biochemical functions of 4-Coumarate Coenzyme A ligase (4CL; EC: 6.2.1.12) genes have been clearly demonstrated in association with monolignol biosynthesis (Lewis and Yamamoto, 1990; Lee et al., 1997; Hu et al., 1998, 1999; Harding et al., 2002). 4CL genes usually exist as a multi-gene family. Four $4 C L$ genes were detected in the Arabidopsis genome and the expression of each member was regulated differentially in tissues and development stages (Raes et al., 2003). In aspen trees, two 4CL genes were cloned and their expression were clearly distinct, with one in epidermal \& leaf tissue and the other specifically in developing xylem tissue (Harding et al., 2002; Hu et al., 1998). Furthermore, the enzymatic activities of $4 C L$ members from aspen, loblolly pine, tobacco, soybean, Arabidopsis, and many other species were found to have distinct substrate specificities (Hu et al., 1998; Lindermayr et al., 2003; Voo et al., 1995). Whether the substrate specificity of the $4 C L$ members relates to different metabolic pathways is unknown. As the 4CL catalytic kinetics vary among species, it is also likely that the mainstream pathway mediated by $4 \mathrm{CL}$ may not be exactly the same in all plant species or tissues. Nevertheless, monolignol biosynthesis is tightly controlled by $4 C L$.

\subsubsection{O-methyltransferases (O-MT)}

S-adenosyl-L-methionine methyltransferases are key enzymes in the phenylpropanoid, flavanoid and many other metabolic pathways in plants. The enzymes Caffeate 3-O methyltransferase (COMT; EC: 2.1.1.68) and Caffeoyl CoA 3-O methyltransferase (CCoAOMT; EC: 2.1.1.104) control the degree of methoxylation in lignin precursors i.e. p- hydroxyphenyl (H), guaiacyl (G) and syringyl (S) units of lignin (Higuchi, 1990; Ralph et al., 1998; Boerjan et al., 2003). The methylation reactions at the C3 and C5 hydroxyl functions of the lignin precursors were thought to occur mainly at the cinnamic acid level via a bifunctional COMT. However, the association of CCOAOMT expression with lignification (Pakusch et al., 1991; Ye et al., 1994; Ye \& Varner, 1995; Ye, 1997; Martz et al., 1998; Chen et al., 2000) and the observation that down-regulation of COMT preferentially affected the amount of $S$ units suggested the existence of an alternative pathway for the methylation of the lignin precursors at the hydroxycinnamoyl CoA level and specific O-methyltransferase i.e. CCoAOMT converts caffeoyl CoA into feruloyl CoA and 5-hydroxyferuloyl CoA into sinapyl CoA (Martz et al., 1998).

\subsubsection{Cinnamoyl CoA reductase (CCR)}

The reduction of cinnamoyl CoA esters to cinnamaldehydes is the first metabolic step committed to monolignol formation (Lacombe \& Hawkins, 1997). This first reductive step in 
lignin biosynthetic pathway is performed by Cinnamoyl CoA reductase (EC: 1.2.1.44) and it controls the over-all carbon flux towards lignin. CCR activity is found to be generally low in plants so it is hypothesized that it may play a crucial role as a rate limiting step in regulation of lignin biosynthesis (Ma \& Tian, 2005). CCR is apparently encoded by a single gene per haploid genome in Eucalyptus (Lacombe \& Hawkins, 1997), poplar (Leple et al., 1998), ryegrass (Larsen, 2004; McInnes et al., 2002), Triticum (Ma, 2007) and tobacco (Piquemal \& Lapierre, 1998) and by two genes in maize (Pichon, Courbou et al., 1998), and Arabidopsis (Lauvergeat \& Lacomme, 2001). The CCR genes in various species appear as a multiple member family. In the Populus genome, there exist $8 C C R$-homolog or CCR-like gene sequences (Li \& Cheng, 2005). Triticum (Ma \& Tian, 2005; Ma, 2007), maize (Pichon \& Courbou, 1998), switchgrass (Escamilla-Trevino \& Shen, 2010), Medicago (Zhou \& Jackson, 2010) and Arabidopsis (Lauvergeat \& Lacomme, 2001) have been shown to possess two or more than two isoforms (CCR1 and CCR2) which are involved in mutually exclusive or redundant functions like, constitutive lignifications and defense. Several other CCR gene sequences have been deposited in the GenBank database, but their functions have still not been demonstrated. It is proposed that all CCR enzymes have a similar catalyzing mechanism for converting the CoA esters to aldehydes in monolignol biosynthesis.

\subsubsection{Coniferaldehyde 5-hydroxylase (CAld5H)}

CAld5H enzyme like $\mathrm{C} 4 \mathrm{H}$ belongs to cytochrome $\mathrm{P} 450$ monoxygenase family. The hydroxylation reaction in the biosynthesis of S-unit (syringyl) was first considered to occur at the ferulate level (Grand, 1984), and hence, the enzyme was called Ferulate 5-hydroxylase $(\mathrm{F} 5 \mathrm{H})$. However, studies later have revealed that $\mathrm{F} 5 \mathrm{H}$ can also function at later steps in the pathway, mainly at the coniferyl aldehyde or coniferyl alcohol level (Humphreys et al., 1999; $\mathrm{Li}$ et al., 2000). This enzyme was therefore alternatively renamed coniferaldehyde- 5hydroxylase (CAld5H) (Osakabe et al., 1999). F5H/CAld5H is unusual in that it is a multifunctional plant P450 with three physiologically relevant substrates. The $\mathrm{Km}$ for the substrates such as coniferaldehyde, coniferyl alcohol and for the ferulic acid are $1 \mu \mathrm{M}, 3 \mu \mathrm{M}$ and $1000 \mu \mathrm{M}$ respectively. This study demonstrates that the coniferaldehyde is the most preferred substrate for the enzymes (Humphrey et al., 1999). Considerable evidence is now available that shows that in angiosperm trees, the syringyl monolignol pathway branches out from guaiacyl pathway through coniferaldehyde and is regulated in sequence by three genes encoding coniferaldehyde 5-hydroxylase $(\mathrm{CAld} 5 \mathrm{H})$, 5-hydroxyconiferaldehyde $O$-methyltransferase (COMT) and sinapyl alcohol dehydrogenase $(S A D)$.

\subsubsection{Cinnamyl/Sinapyl alcohol dehydrogenases (CAD/SAD)}

In gymnosperm wood, coniferyl alcohol is the major monolignol units while both coniferyl and sinapyl alcohols are present in angiosperm wood. CAD (E.C: 1.1.1.195), depicts a class of NADPH dependent oxidoreductase, suggested to catalyze multiple cinnamyl alcohol formations from their corresponding cinnamaldehydes (Lewis \& Yamamoto, 1990; Whetten \& Sederoff, 1995; Whetten et al., 1998). This reduction of aldehydes to corresponding alcohols has been considered to be an indicator of lignin biosynthesis because of its specific role at the end of the monolignol biosynthesis pathway (Baucher et al., 1996). When the Populus tree was studied for monolignol biosynthesis in wood forming tissue, in addition to $C A D$, it was found in aspen that another gene, its sequence similar to but distinct from $C A D$, is also associated with lignin biosynthesis (Li et al., 2001). The biochemical characterization of the recombinant protein encoded by this gene indicated that the 
enzymatic activity has specific affinity toward sinapaldehyde, therefore it was named SAD. Compared with SAD enzyme kinetics, CAD showed a catalytic specificity towards coniferaldehyde instead. The catalytic specificities of the two enzymes have been further verified in protein structure analysis (Bomati \& Noel, 2005). Furthermore, it was demonstrated that the expression of $C A D$ is associated with G-lignin accumulation while $S A D$ was associated with S-lignin formation during xylem differentiation ( $\mathrm{Li}$ et al., 2001). The evidence from molecular, biochemical and cellular characterizations strongly suggest that $C A D$ is involved in G-monolignol biosynthesis and $S A D$ in S-monolignol biosynthesis in aspen wood formation.

\subsubsection{Transport of monolignols}

After the synthesis, the lignin precursors or monolignols are transported to the cell wall where they are oxidized and polymerized. The monolignols formed are insoluble and toxic to the plant cell and hence are converted to their respective glucosides by the action of UDPglycosyltransferases (UDP-GT). This conversion renders the monolignols, soluble and less toxic to the plant cells, which can be stored in plant vacuoles, and transported to the cell wall as the need arises. It has been hypothesized that these monolignol glucosides are storage or transport forms of the monolignols (Steeves et al., 2001).

\subsubsection{Dehydrogenation and polymerization}

After transport of the monolignols to the cell wall, lignin is formed through dehydrogenative polymerization of the monolignols (Christensen et al., 2000). The dehydrogenation of monolignol radicals has been attributed to different class of enzymes, such as peroxidases (POX), laccases (LAC), polyphenol oxidases, and coniferyl alcohol oxidase. Lignin is a hydrophobic and optically inactive polymer, which is highly complex and heterogeneous in nature. Lignin polymerization is a radical coupling reaction, where the monolignols are first activated into phenoxy radicals in an enzyme catalyzed dehydrogenation reaction. These radicals couple to form dimers, oligomers and eventually the lignin polymer (Freudenberg, 1968). Peroxidases are heme-containing oxidoreductases that use $\mathrm{H}_{2} \mathrm{O}_{2}$ as the ultimate electron acceptor. The natural electron donor molecules in a peroxidase catalyzed reaction vary and include, monolignols, hydroxycinnamic acids (Zimmerlin et al., 1994), tyrosine residues in extensions (Brownleader et al., 1995) and auxin (Hinman \& Lang, 1965). Several reports on peroxidase activity or gene expression in ligninforming tissues have appeared, but only a few isoenzymes or genes have been specifically associated with lignification (Christensen et al., 2001; Marjamaa et al., 2006; Quiroga et al., 2000; Sato et al., 1993).

\subsection{Regulation of monolignol biosynthesis}

Developmental program of lignification associated with certain types of plant cells, such as xylem and fibers, require coordinated regulation of different lignin biosynthesis genes, as well as with genes controlling other aspects of plant growth and development. Different transcription factors such as R2R3-MYB, KNOX, MADS, LIM have been found to be regulating lignin biosynthesis in many plants, although the understanding of the molecular mechanism of pathway regulation is still limiting (Campbell \& Rogers, 2004; Zhou et al., 2006, 2008). Lignification can be modified in a more efficient and precise way by 
understanding the regulation of these pathways via altering the expression of relevant transcription factors.

\section{Lignin as barrier for paper production}

From an agro-economical point of view, lignin is considered to have a negative impact because it affects the paper manufacture and limits digestibility of forage crops. High quantity and low Syringyl (S) to Guaiacyl (G) lignin ratio plays a detrimental role in economy and ecology of paper production. Every unit increase in S/G ratio decreases the cost of paper production by two and half times. Both lignin content and composition are known to have impact on pulp \& paper because residual lignin in the wood fibers causes a discoloration and a low brightness level of the pulp (Chaing et al., 1988). Consequently, for the production of high quality paper, lignin has to be removed from cellulose during the pulping process without damaging the polysaccharide component of wood. During chemical (Kraft) pulping, a large amount of Sodium hydroxide $(\mathrm{NaOH})$ and Sodium sulfide $\left(\mathrm{Na}_{2} \mathrm{~S}\right)$ are required to extract lignin from the pulp (Axegard et al., 1992). Subsequently, the residual lignin is further removed with bleaching agents, such as Chlorine dioxide $\left(\mathrm{ClO}_{2}\right)$, Hydrogen peroxide $\left(\mathrm{H}_{2} \mathrm{O}_{2}\right)$, Sodium hypochlorite $(\mathrm{NaOCl})$, Oxygen $\left(\mathrm{O}_{2}\right)$, or Ozone $\left(\mathrm{O}_{3}\right)$ (Axegard et al.,1992; Biermann, 1993; Christensen et al., 2000).

These lignin extraction \& bleaching procedures can partly degrade cellulose and consequently, reduce pulp quality and paper strength. Lignin extraction consumes large quantities of chemicals and energy leading to poor environmental image for these industries (Biermann, 1996; Higuchi, 1985; Odendahl, 1994). For this reason, engineering of plants with cell wall structures that are more susceptible to the krafting, and thus, more amenable to hydrolysis, or are sufficiently altered so as to shunt the above processes is an attractive approach to improve pulping efficiency and potentially alleviate some of the negative environmental impacts of the paper making industry. Apart from the great deal of work in the lignin field for improving the pulping process, many examples can be found based on research aimed at altering the lignin content for improving bio-fuel production (Chen, 2006; Chen \& Dixion, 2007; Davision, 2006; Franke et al., 2002), as well as for improving forage crop digestibility (Table 1 ).

\section{Genetic engineering of phenylpropanoid biosynthetic pathway}

Despite the extensive literature on genetic modifications of lignin biosynthesis in a variety of plants, only a few studies have reported the impact of modified lignin content and composition on pulping and bleaching processes. Nevertheless, significant progress has been made in this field, as summarized in Table 1.

Emerging genetic engineering strategies in planta including manipulation of lignin biosynthesis at regulatory level, controlling monolignol polymerization enzymes, and modifications of lignin polymer structure, together with exploration of lignin degrading enzymes from other organisms provide us the necessary tools for producing designer plant species with reduced/altered lignin traits, so as to meet the needs of paper, livestock industries, etc. However, traditional genetic engineering strategies such as upregulation and downregulation of monolignol biosynthetic genes are still applied and have been successful in facilitating lignin decomposition by altering both lignin content and composition. One 
such example based on genetic modifications in Leucaena is described here, providing insights into the reactions, and regulation of genes involved in lignin biosynthesis, and its impact on determining lignin quality for paper industries.

\begin{tabular}{|c|c|c|c|c|c|}
\hline Plant & Gene & $\begin{array}{l}\text { Lignin } \\
\text { Content }\end{array}$ & $\begin{array}{c}\text { Lignin } \\
\text { Composition }\end{array}$ & Phenotype & References \\
\hline \multirow[t]{6}{*}{ Medicago } & CAD & Reduced & S/G Ratio $\downarrow$ & Forage Digestibility $\uparrow$ & Baucher et al., 1999 \\
\hline & HCT & " & - & 0 & Shadle et al., 2007 \\
\hline & $\mathrm{C} 3 \mathrm{H} / \mathrm{HCT}$ & " & $\mathrm{H} / \mathrm{G} \uparrow$ & “ & Ziebell et al., 2010 \\
\hline & СP 450 enzymes & " & - & " & Reddy et al., 2005 \\
\hline & OMT & $"$ & - & Cellulose content $\uparrow$ & Marita et al., 2003 \\
\hline & ССОАОМТ & “ & - & Forage Digestibility $\uparrow$ & Guo et al., 2001 \\
\hline \multirow[t]{4}{*}{ Nicotiana } & PAL/CCOAOMT & “ & S/G Ratio $\uparrow$ & & Sewalt et al., 1997 \\
\hline & CCR & “ & S/G Ratio $\uparrow$ & Pulping Efficiency $\uparrow$ & O'Connell et al., 2002 \\
\hline & CAD & Unchanged & Aldehyde units $\uparrow$ & 列 & Halpin et al., 1994 \\
\hline & CAD/CCOAOMT & " & S/G Ratio $\downarrow$ & Forage Digestibility $\uparrow$ & Vailhe et al., 1998 \\
\hline \multirow{7}{*}{$\begin{array}{c}\text { Arabidopsis } \\
\text { Alfalfa }\end{array}$} & POX & Reduced & S/G Ratio $\uparrow$ & Saccharification $\uparrow$ & Kavousi et al., 2010 \\
\hline & CCR & $"$ & - & Forage Digestibility $\uparrow$ & Goujon et al., 2003 \\
\hline & $\mathrm{C} 4 \mathrm{H}$ & “ & S/G Ratio $\downarrow$ & $"$ & Reddy et al., 2005 \\
\hline & HCT & “ & High $\mathrm{H}$ & “ & Shadle et al., 2007 \\
\hline & $\mathrm{C} 3 \mathrm{H}$ & " & 0 & “ & Reddy et al., 2005 \\
\hline & ССоАОМТ & “ & S/G Ratio $\uparrow$ & “ & Guo et al., 2001a, b \\
\hline & Cald5H & Unchanged & S/G Ratio $\downarrow$ & Unchar & Reddy et al., 2005 \\
\hline \multirow{4}{*}{ Populus } & CAD & & & Forage Digestibility $\uparrow$ & Baucher et al., 1999 \\
\hline & COMT & Reduced & “ & Pulping Efficiency $\downarrow$ & Jouanin et al., 2000 \\
\hline & ССоАОМТ & te & S/G Ratio $\uparrow$ & Pulping Efficiency $\uparrow$ & Petit, Conil et al., 1999 \\
\hline & CAD & Unchanged & Aldehyde units $\uparrow$ & & Lapierre et al., 2004 \\
\hline \multirow{5}{*}{$\begin{array}{c}\text { Picea } \\
\text { Festuca } \\
\text { Maize } \\
\text { Linum }\end{array}$} & $4 \mathrm{CL}$ & Reduced & $\begin{array}{c}\text { free phenolics } \\
\text { S/G Ratio } \downarrow\end{array}$ & Cellulose content $\uparrow$ & Voelker et al., 2010 \\
\hline & CCR & $"$ & H/G Ratio $\downarrow$ & Pulping Efficiency $\uparrow$ & Wadenback et al., 2007 \\
\hline & CAD & " & - & Forage Digestibility $\uparrow$ & Chen et al., 2003 \\
\hline & COMT & “ & S/G Ratio $\downarrow$ & 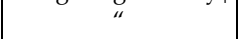 & He et al., 2003 \\
\hline & СCoAOMT & “ & & - & Day et al., 2009 \\
\hline
\end{tabular}

Table 1. Genetic engineering of different lignin biosynthetic genes, and their effects on lignin contents and composition

\section{Level of Control for Genetic manipulation of Lignin}

\begin{tabular}{|c|c|c|c|}
\hline 1 & 2 & 3 & 4 \\
\hline $\begin{array}{l}\text { Synthesis of monolignols } \\
\text { (PAL, C4H, COMT, } \\
\text { CCOAOMT, 4CL,CCR, CAD) }\end{array}$ & $\begin{array}{l}\text { Transport of monolignols } \\
\text { to the site of } \\
\text { polymerization } \\
\text { (UDP-GTs , BG) }\end{array}$ & $\begin{array}{l}\text { Polymerization of } \\
\text { monolignols } \\
\text { (LAC, POX) }\end{array}$ & $\begin{array}{l}\text { Manupulation at } \\
\text { regulatory level } \\
\text { (R2-R3 Myb) }\end{array}$ \\
\hline
\end{tabular}

Fig. 3. Levels of control for manipulation of lignin biosynthesis. The control level 1 involves manipulation of lignin biosynthetic genes; level 2 and 3 involves manipulation of genes involved in transport and polymerization of monolignols; while level 4 deals with manipulations of different regulatory factors

\subsection{Leucaena leucocephala as a source of pulp}

A great deal of knowledge on the molecular biology and regulation of phenylpropanoid biosynthesis has been derived from investigations in plants such as Arabidopsis, Alfalfa etc. 
While these models will continue to serve as platforms for studying lignifications, a number of other plant species, e.g., Leucaena leucocephala have recently been selected for such studies. The paper industry in India mainly uses bamboos, Eucalyptus sp., Casuarina sp. and Leuacaena sp. as a source for paper pulp. Selection of the species depends upon availability, price and acceptability by any given industrial unit. However Leucaena sp. is extensively used in India and nearly a quarter of raw materials for paper and pulp industry comes from this plant (Srivastava et al., 2011). Leucaena is also valued as an excellent source of nutritious forage.

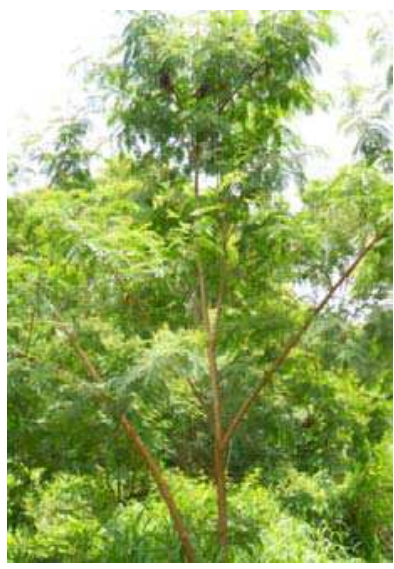

(a)

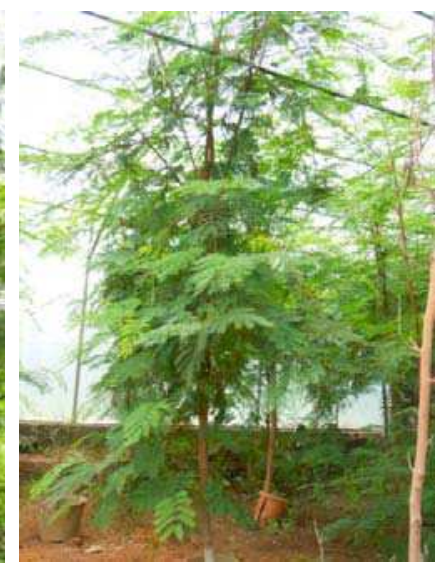

(b)

Fig. 4. (a) Leucaena leucocephala cv. K-636 growing at NCL premises, (b) A transgenic plant cultivated in our green-house. (Photographs courtesy of Shakeel Abbassi, NCL)

It has been estimated that dried leaves of Leucaena contain nearly $28-35 \%$ of protein content of high nutritional quality. Besides this, Leuceana is also an excellent source of firewood, industrial fuel, organic fertilizer, timber and gum (Cottom et al., 1977). A native of Central America, Leucaena has been naturalized pan-tropically, with members of its genera being vigorous, drought tolerant, highly palatable, high yielding \& rich in protein and grow in wide range of soils (Hughes, 1998; Jones, 1979). However, these attributes are limited by the occurrence of anti-nutritive factors in the fodder, such as tannins and mimosine (Hammond et al., 1989; Hegarty et al., 1964; Jones, 1979).

\subsection{Phenylpropanoid biosynthesis genes from Leucaena leucocephala}

Different genes involved in phenylpropanoid biosynthesis were studied in detail from Leucaena. Table 2 summarizes the details of such genes isolated from Leucaena along with their GenBank accession numbers.

\subsection{Regeneration system of Leucaena leucocephala}

Genetic transformation of plants needs reproducible robust regeneration system. Regeneration of complete plants through tissue culture has made it possible to introduce foreign genes in to plant genome and recover transgenic plants. The limited success rate for 


\begin{tabular}{|c|c|c|c|c|c|}
\hline Name of Genes & $\begin{array}{c}\text { Accession } \\
\text { Nos. }\end{array}$ & $\begin{array}{c}\text { cDNA, } \\
\mathbf{k b}\end{array}$ & $\begin{array}{c}\text { Amino } \\
\text { acid no. }\end{array}$ & $\begin{array}{c}\text { Mm, } \\
\text { kDa }\end{array}$ & Annotations \\
\hline PAL & JN540043* & -- & -- & -- & Ll-PAL \\
\hline C4H & GU183363 & 1.836 & 505 & 57.94 & LlC4H1 \\
& HQ191221 & 1.761 & 505 & 57.93 & LlC4H2 \\
& HQ191222 & 1.760 & 505 & 57.99 & LlC4H3 \\
\hline 4CL & FJ205490 & 1.935 & 542 & 58.87 & 4 CL 1 \\
& FJ205491* & 1.831 & 519 & 56.74 & 4 CL2 \\
\hline CCoAOMT & DQ431234 & 0.735 & 244 & 27.55 & CCoAOMT2 \\
& DQ431233 & 0.735 & 244 & 27.57 & CCoAOMT1 \\
\hline CCR & EU195224 & 1.005 & 334 & 36.30 & Ll-CCRH2 \\
& DQ986907 & 1.011 & 336 & 36.52 & Ll-CCRH1 \\
\hline CAld5H & EU041752 & 1.826 & 511 & 57.42 & Ll-Cald5H \\
\hline CAD & EU870436 & 1.178 & 357 & 38.87 & Ll-CAD \\
\hline Lignin POX & GU143879 & 0.951 & 316 & 33.94 & POX1 \\
& GU143878 & 0.951 & 316 & 34.03 & POX2 \\
& EU649680 & 0.951 & 316 & 34.20 & Ll-POX \\
\hline Glucosylhydrolase & EU328158 & 1.524 & 507 & 57.57 & Ll-GH Family 1 \\
\hline R2R3 MYB factor & GU901209 & 0.911 & 235 & 26.50 & Ll_R2R3_MYB2_SSM \\
\hline Cellulose & FJ871987 & 3.391 & 1075 & 123.30 & Ll-7CesA \\
Synthase(CesA) & GQ267555 & 3.368 & 1073 & 119.97 & Ll-8CesA \\
\hline
\end{tabular}

Table 2. Phenylpropanoid biosynthesis genes from Leucaena: C4H: Cinnamate 4-Hydroxylase; 4CL: 4 Coumarate CoA Ligase; CCoAOMT: Caffeoyl CoA O-Methyl Transferase; COMT: Caffeate O-Methyl Transferase; CCR: Cinnamoyl CoA Reductase; CAld5H: Coniferaldehyde 5-Hydroxylase; CAD: Cinnamyl Alcohol Dehydrogenase; POX: Peroxidase; *Partial sequence

regeneration of leguminous trees has been reported in few research works. The complete in vitro plantlet regeneration of Leucaena (Cultivar, K-67) from lateral bud explants has been optimized with the maximum shoot multiplication rate of 22 shoots per explants. These regenerated plantlets were transplanted ex vitro with $80 \%$ survival rates (Goyal et al., 1985). In addition to the regeneration from lateral bud explants, an alternative (both direct and callus mediated/indirect) plantlet regeneration system has been successfully demonstrated with $100 \%$ regeneration frequency using cotyledon explants from 3-4 days old plants (Cultivar, K-636). It is interesting to note that the plantlets regenerated from cotyledonary explants rooted without any requirements of growth regulators on basal media (Saafi et al., 2002). Addition of Thidiazuron (TDZ) to the shoot induction medium has substantially improved the number of in vitro shoots per explants as compared to the basal shoot induction medium with N6-Benzyladenine (BA). Liquid pulse treatment of the induced shoots with TDZ resulted in the improvement in the subsequent rooting. The plantlets regenerated in this manner showed more than $90 \%$ survival rate ex vitro when grown in coco-peat mixture (Shaik et al., 2009). In order to improve overall in vitro plantlet regeneration efficiency, attempts to propagate elite (cultivar K-8, K-636) and wild type varieties of Leucaena were made by supplementing the basal shoot induction media with puterscin. It has been observed that putriscine $(9.3 \mu \mathrm{M})$ significantly enhanced the number of regenerated shoots from hypocotyls explants when compared to the induction medium containg only BA $(22.2 \mu \mathrm{M})$. The incidence of yellowing and leaf abscission was successfully 
abridged by addition of glutamine $(685 \mu \mathrm{M})$ or adenine $(540 \mu \mathrm{M})$ which indirectly added ex vitro survival of the plants. All the regenerated plantlets from hypocotyls explants exhibited $100 \%$ in vitro rooting and were subsequently transplanted ex vitro (Sirisha et al., 2008). In vitro regeneration system for some other cultivars of Leucaena (K-8, K-29, K-68 and K-850) from mature trees derived nodal explants as well as seedlings derived cotyledonary node explants have also been reported, where cultivar K-29 gave the best response in vitro. Indirect (through callus phase) somatic embryogenesis of cv. K-29 using $40.28 \mu \mathrm{M}$ NAA and 12.24 $\mathrm{\mu M}$ were also established. These somatic embryos were further matured in full strength medium (Rastogi et al., 2008).

Considering all above discussed reports, it can be suggested that our reports (Shaik et al., 2009) of improved method also have produced a consistent regeneration system for Leucaena which will be beneficial for the mass propagation and genetic transformation of Leucaena species. Lignin content in wood pulp adversely influences the quality of paper produced. In Leucaena which is an important paper pulp wood crop, it becomes important to identify and multiply elite clones having naturally low lignin content. In addition to this approach there is a need to develop transgenic plants with altered or reduced lignin content for its efficient and eco-friendly removal from pulp. The above mentioned multiple regeneration pathways are an excellent tool to introducing foreign genes. Out of all these methods shoot regeneration from cotyledonary node explants are more responsive to multiple shoot induction (Hussain et al., 2007). Genetic transformation procedures particularly particle bombardment which is considered as most effective means of gene delivery can be applied to the transformation of these shoot meristems. Cotyledonary explant derived multiple shoots form most suitable tissue for genetic transformation due to their higher regeneration frequency. Therefore, our recent study dealt with multiple shoot induction from the cotyledonary nodes of Leucaena in response to cytokinins, thidiazuron (TDZ) and N6benzyladenine (BA) supplemented in half strength MS (1/2-MS) medium and also their effect on in vitro rooting of the regenerated shoots (Fig. 5). The addition of cytokinins to the medium was found essential for multiple shoot induction. Leucaena cotyledonary nodes carried a high potential for rapid multiple shoot regeneration on medium containing lower concentrations of TDZ (0.05 or $0.23 \mu \mathrm{M})$ (Shaik et al., 2009). As multiple shoots originated from the mass of closely placed shoot initials of axillary meristems (Fig. 5), this system could be efficiently used for particle bombardment mediated transformation. This efficient and high frequency in vitro regeneration system is highly reproducible and can be used for mass propagation and genetic transformation of Leucaena.

\subsection{Genetic transformation of Leucaena}

The genetic transformation protocols based on Agrobacterium-mediated and/or direct gene transfers by biolistic bombardment have been successfully applied to numerous woody angiosperm species (Merkle \& Nairn, 2005), including Populus and Betula. The introduction of transgenes have included both sense and antisense strategies (referring to the orientation of the introduced gene into the plant genome) (Strauss et al., 1995; Baucher et al., 1998) and RNAi technology (Merkle \& Nairn, 2005). In the antisense strategy, duplex formation between the antisense transgene and the endogenous gene transcripts is proposed to induce the degradation of duplexes and, correspondingly, lead to suppressed gene expression (Strauss et al., 1995). Regeneration system for Leucaena has already been established in our previous works (Shaik et al., 2009; Sirisha et al., 2008). To exploit this to produce transgenic 
Leucaena plants for reduced/altered lignin content, various phenylpropanoid pathway genes $(\mathrm{C} 4 \mathrm{H}, 4 \mathrm{CL}, \mathrm{CCoAoMT}, \mathrm{CCR}, \mathrm{CAld} 5 \mathrm{H}, \mathrm{CAD}$ and POX) were cloned and used for transformation experiments.
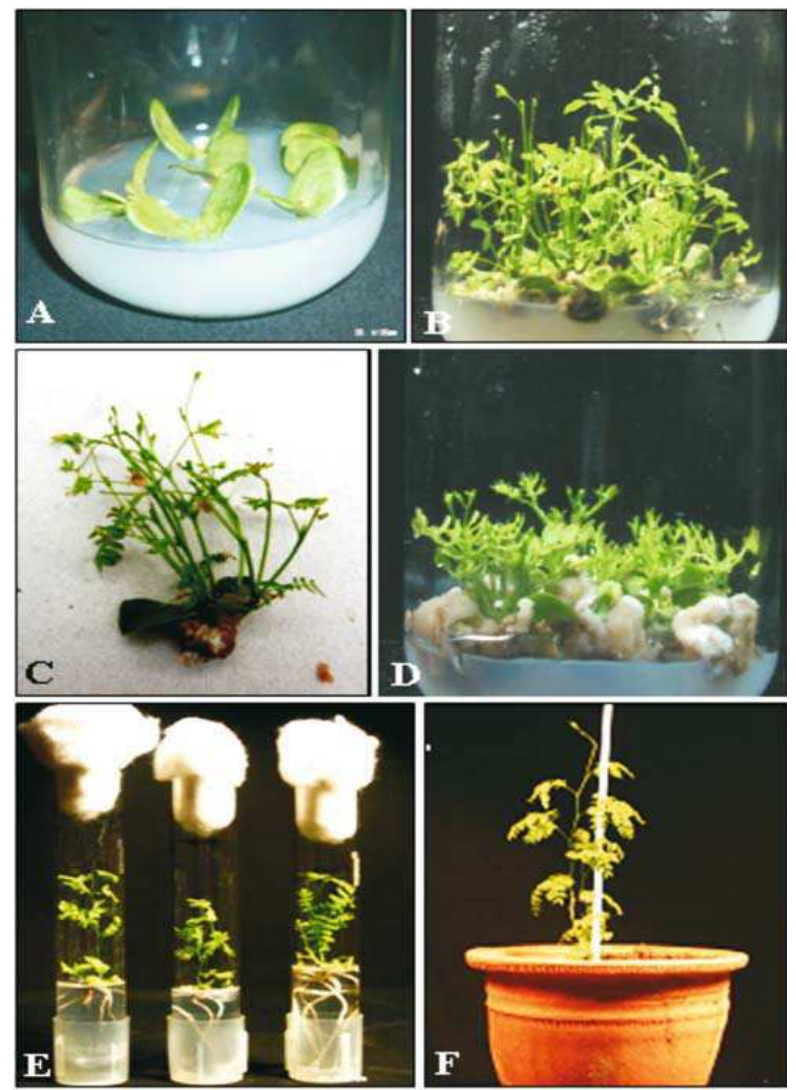

Fig. 5. In vitro shoot regeneration in L. leucocephala (cultivar K-636). A: Cotyledonary nodes, B-C: Multiple shoot induction in cotyledonary nodes on $1 / 2-\mathrm{MS}+\mathrm{TDZ}(0.23 \mu \mathrm{M})$, D: Shortened and fasciated shoots of Leucaena on $1 / 2-\mathrm{MS}+\mathrm{TDZ}(0.45 \mu \mathrm{M})$, E: Rooted shoots of Leucaena on $1 / 2$-MS + NAA $(0.54 \mu \mathrm{M})$ and F: Hardened in vitro propagated plant of $L$. leucocephala in Sand: soil mixture. (Shaik et al., 2009)

One day old embryo axes without cotyledons were used as explants for transformation. It was carried out by three methods: 1) Particle bombardment; 2) Particle bombardment followed by co-cultivation and 3) Agro-infusion method. The transformation efficiencies with various gene constructs are summarized in Table 3. It can be observed that maximum efficiency $(100 \%)$ was noted with CAD using particle bombardment followed by cocultivation as a means of transformation. However, CCR with the same procedure gave only $10 \%$ efficiency. In general it was concluded that a combination of particle bombardment method followed by co-cultivation was most effective in transforming the shoot meristems of Leucaena. 


\begin{tabular}{|c|c|c|c|c|c|c|c|c|}
\hline Gene & Method & $\begin{array}{c}\text { No. of } \\
\text { embryo } \\
\text { axis used }\end{array}$ & $\begin{array}{c}\text { No. of } \\
\text { explants } \\
\text { survived }\end{array}$ & $\begin{array}{c}\text { No. of shoots } \\
\text { elongated }\end{array}$ & $\begin{array}{c}\text { Avg. shoot } \\
\text { length* }\end{array}$ & $\begin{array}{c}\text { No. of shoots } \\
\text { used for DNA } \\
\text { extraction }\end{array}$ & $\begin{array}{c}\text { No. PCR } \\
\text { +ve } \\
\text { samples }\end{array}$ & $\begin{array}{c}\text { Transformation } \\
\text { efficiency (\%)\# }\end{array}$ \\
\hline CCR & $P B$ & 67 & 59 & 30 & 3.67 & 8 & 4 & 50 \\
\hline CCR & $P B+C C$ & 107 & 94 & 40 & 2.97 & 20 & 2 & 10 \\
\hline CCR & $A I$ & 43 & 6 & 6 & 2.07 & 6 & 1 & 16.66 \\
\hline 4CL1 & $P B$ & 231 & 205 & 154 & 3.72 & 154 & 92 & 59.74 \\
\hline 4CL1 & $P B+C C$ & 109 & 83 & 47 & 3.41 & 47 & 38 & 80.85 \\
\hline 4CL1 & $A I$ & 60 & 22 & 04 & 1.17 & 4 & 2 & 50 \\
\hline CAD & $P B$ & 438 & 208 & 42 & 3.06 & 11 & 7 & 63.63 \\
\hline CAD & $P B+C C$ & 173 & 114 & 11 & 2.49 & 2 & 2 & 100 \\
\hline CAD & $A I$ & 147 & 32 & 16 & 1.68 & 6 & 6 & 100 \\
\hline CAld5H & $P B$ & 74 & 54 & 25 & 3.47 & 7 & 2 & 28.57 \\
\hline CAld5H & $P B+C C$ & 99 & 74 & 31 & 2.79 & 14 & 11 & 78.57 \\
\hline CAld5H & $A I$ & 34 & 5 & 4 & 2.00 & 2 & - & - \\
\hline C4H & $P B$ & - & - & - & - & - & - & - \\
\hline C4H & $P B+C C$ & 615 & 61 & 11 & 3.5 & 10 & 6 & 60 \\
\hline C4H & $A I$ & - & - & - & - & - & & - \\
\hline POX & $P B$ & 58 & 47 & 44 & 1.36 & 23 & 17 & 73.91 \\
\hline POX & $P B+C C$ & 79 & 64 & 59 & 1.38 & 31 & 27 & 87.09 \\
\hline POX & $A I$ & 32 & 23 & 19 & 1.15 & 9 & 5 & 55.56 \\
\hline
\end{tabular}

Table 3. Transformation efficiency of Leucaena downregulated with phenylpropanoid pathway genes using different methods. PB, Particle Bombardment; CC, Co-Cultivation; AI, Agro Infusion. *Measured after 3 rounds on selection, \#Calculated as per the number of plants screened

\subsubsection{Peroxidase (LIPOX): A case study}

Numerous reports on peroxidase activity in lignin forming tissues have been reported, but only a few isoenzymes have been specifically associated with lignification (Sato et al.,1993; Quiroga et al., 2000; Christensen et al., 2001; Marjamaa et al., 2006). It is likely that the control of the whole lignification process requires a mechanism for the co-ordinated expression and/or activation of the monolignol biosynthetic genes/enzymes and the radical forming peroxidases. Data from transgenic plants down regulated for peroxidase activity has confirmed the role of some POX isoforms in lignin polymerization in tobacco and Populus sieboldii (Miq.)X Populus grandidentata (Michx.) (Talas-Ogras et al., 2001; Blee et al., 2003; Li et al., 2003b). Both quantitative (up to $50 \%$ reduction) and qualitative changes were reported, but no obvious growth phenotypes, other than larger xylem elements were found.

Recombinant pCAMBIA1301 binary vector harboring partial sequence of LIPOX in antisense orientation was used to transform the embryos isolated from aseptically germinated seeds of Leucaena (Fig. 6). Two fragments (one from conserved region and another from nonconserved region) of LIPOX cloned in anti-sense orientation were used for transformation. The Leucaena embryo axes were bombarded with microcarriers coated with recombinant pCAMBIA vectors using PDS-1000/He Biolistic Particle Delivery System. After growing the embryos on regeneration media without selection for one week, these embryos were subjected to three rounds of selections. The plants, which survived were shifted to $1 / 2-\mathrm{MS}$ with Cytokinin, 2-ip (2-isopentenyl adenine) $0.5 \mathrm{mg} / \mathrm{L}$ to enhance elongation of transformed shoots. In all the above cases, the bombarded explants were subjected to transient GUS assay $48 \mathrm{hrs}$ after second bombardment and the putative transgenic plants, which survived three rounds of selection, were analyzed for the gene integration into the plant genome.

As an alternative strategy, Leucaena embryo axes were also transformed by a combination of particle bombardment followed by co-cultivation with Agrobacterium (GV2260) harboring 

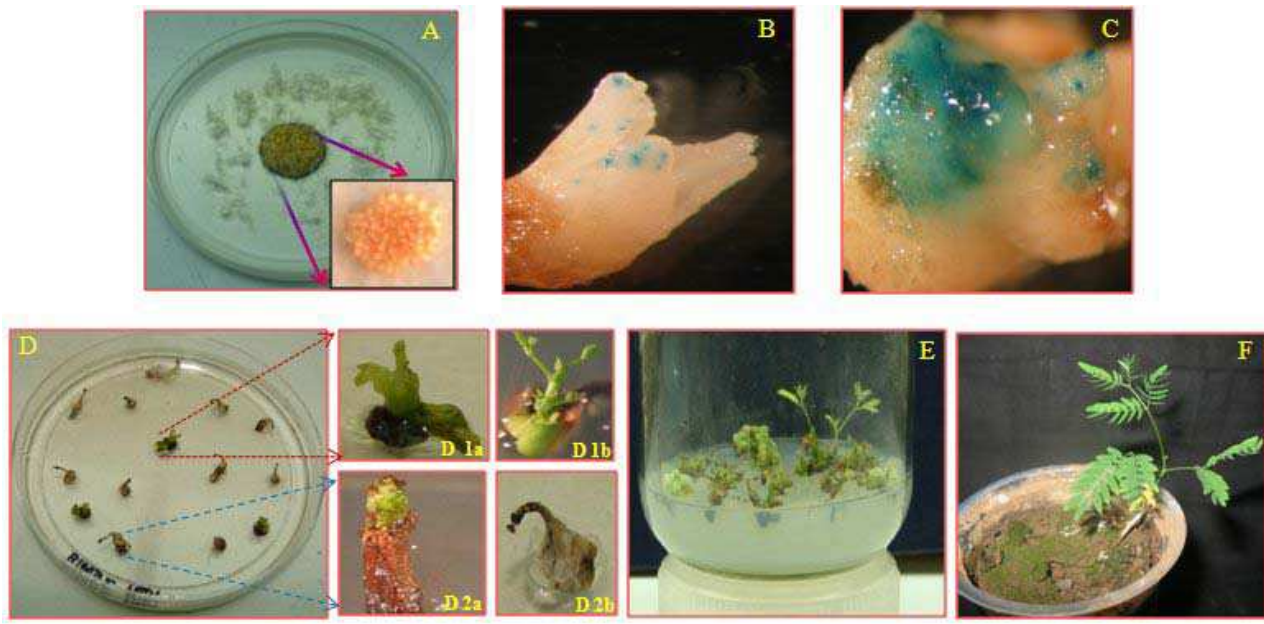

Fig. 6. Genetic transformations in Leucaena leucocephala by particle bombardment method using Anti-LIPOX construct. A: Embryos arranged for bombardment, B-C: Transient GUS expression, D. Bombarded embryos on selection, D1a and D1b. Regenerating embryos on selection, D2a and D2b. Necrosis and dying of untransformed embryos on selection, E-F: Regeneration and hardening of putative transformants

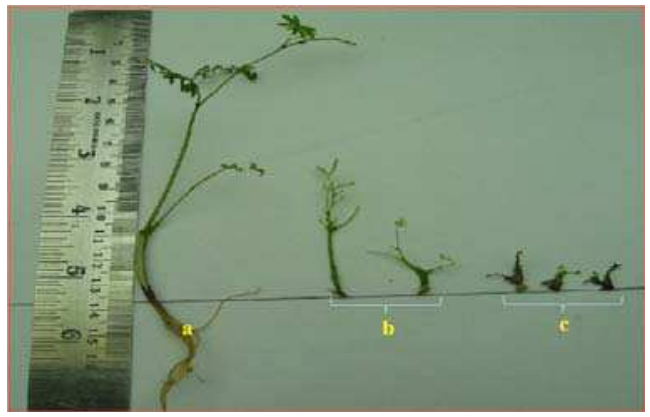

Fig. 7. a. Untransformed plant not subjected to genetic transformation, b. putative transformants using construct Anti-LIPOX (NC) of POX gene and c. putative transformants using constructs Anti-LlPOX (C) of POX gene. NC-Non conserved; C-Conserved

respective recombinant pCAMBIA vectors. After particle bombardment, the embryo axes were then transferred onto the respective regeneration medium, co-cultivated in the dark at $25 \pm 2{ }^{\circ} \mathrm{C}$ for 3 days. After co-cultivation, the embryo axes were washed thoroughly with Cefotaxime $250 \mathrm{mg} / \mathrm{L}$ in sterile distilled water and transferred onto the regeneration medium. Higher levels of transient GUS expression confirmed the transformation efficiency. The present study was performed using, two different antisense constructs of Leucaena peroxidase gene. We observed severe stunted or retarded growth in plants when transformed using constructs having conserved domain. These plants were found to grow barely up to $0.5 \mathrm{~cm}$, soon followed by the death of the apical meristem and rise of a fresh axillary bud from its axis, which again dies and this process was found to be repeating. As a 
result, the plant attained a height of $2.5 \mathrm{~cm}$ on an average and even failed to produce roots when transferred to rooting medium. When non-conserved AntiPOX construct was used in Leucaena transformation, normal regeneration was noticed but the plants were thin and slow growing compared to the untransformed control plants. Comparative growth pattern of Leucaena are shown in Fig. 7.

LIPOX was immuno-cytolocalized in the transformants generated following the above mentioned protocols. Control and transformed plants of same age group were selected. The control plants showed better growth and bio-metric parameters (height, growth and rooting) over the transformants. POX was immuno-cytolocalized in stem tissues of control untransformed plants (Fig. 8 A, B, C) and putative transformants (Fig. 8 D, E, F), with a view to find whether there exists reduction in peroxidase expression in lignifying tissues (i.e vascular bundle and xylem fibres). It was observed that the transformants showed reduced levels of POX near the sites of lignifications. It was also noted that Leucaena transformed by AntiLIPOX from conserved region resulted in discontinuity in vascular bundle assemblies.

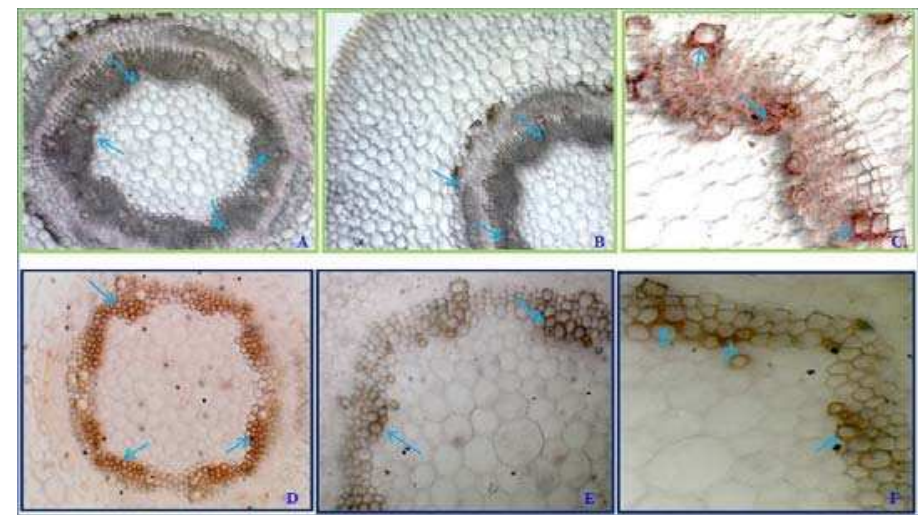

Fig. 8. Immuno-cytolocalization of POX in Leucaena. A, B \& C stem sections of control plants showing higher levels of POX protein on xylem tissues over the transformed plants D, E \& F. Control plants show a well developed vascular bundles (continuous ring) over transformants (discontinuous ring)

\begin{tabular}{|l|c|c|}
\hline Genes Down-regulated & Morphological Changes & Reduction in Lignin content \\
\hline $4 C L$ & No change & $2-7 \%$ \\
\hline$C A l d 5 H$ & No change & Yet to be analyzed \\
\hline$C C R$ & Stunted growth & $4-13 \%$ \\
\hline$C A D$ & Stunted growth & $2-8 \%$ \\
\hline$C 4 H$ & Stunted growth & Yet to be analyzed \\
\hline$P O X(N C)$ & Stunted Growth & $4-9 \%$ \\
\hline$P O X(C)$ & $\begin{array}{c}\text { Stunted and abnormal } \\
\text { growth pattern }\end{array}$ & $6-14 \%$ \\
\hline
\end{tabular}

Table 4. Lignin estimation of transgenic Leucaena plants. NC-Nonconserved; C-conserved

Likewise, rest of the antisense constructs (4CL, CAld5, CCR, CAD, and C4H) were successfully utilized for genetic transformation of Leucaena and were subsequently 
characterized for transformation efficiency and lignin content (Table 4). Plants having antisense construct of $C 4 H, C C R, C A D$ and $P O X$ showing stunted growth. But in case of $4 C L$ transformants no such morphological appearance were observed.

\section{Conclusions}

Thanks to years of painstaking research in to the chemistry of lignin, it is now seen as a potential target for genetic engineering of plants, mostly aggravated by its industrial and agricultural applications. However, much of our understanding of lignin biochemistry comes from studies of model plants like Arabidopsis, Tobacco, Poplar, etc. Furthermore, this technology needs to be transferred to other plant species. Leucaena, a multiple utility leguminous tree, is targeted for ongoing research to alter its lignin content due to its importance in paper and pulp industry in India. Keeping this in mind, attempts were made to improve pulp yielding properties by genetically engineering lignin metabolism so as to gratify the demand of such industries. The results presented here highlight the challenges and limitations of lignin down-regulation approaches: it is essential but difficult to find a level of lignin reduction that is sufficient to be advantageous but not so severe as to affect normal growth and development of plants.

These findings may contribute in the development of Leucaena with altered lignin composition/content having higher lignin extractability, making the paper \& pulp industry more economic and eco-friendly. The multi-purpose benefits of lignin down regulation in this plant can also be extrapolated to improved saccharification efficiency for biofuel production and forage digestibility, apart from enhanced pulping efficiency. Although genetic engineering promises to increase lignin extraction and degradability during the pulping processes, the potential problems associated with these techniques, like increased pathogen susceptibility, phenotypic abnormalities, undesirable metabolic activities, etc. must be addressed before its large scale application. In order to overcome such barriers, significant progress must be made in understanding lignin metabolism, and its effects on different aspects of plant biology.

Nevertheless, the current genetic engineering technology provides the necessary tools for a comprehensive investigation for understanding lignin chemistry, which were hardly possible using classical breeding methods.

\section{Acknowledgements}

Authors would like to thank the research grant funded by Council of Scientific and Industrial Research (CSIR) NIMTLI, India. The project was conceived by SKR and BMK. SS and AKY acknowledges UGC-CSIR; MA, SKG, NMS, PSK, AOU, RKV, SK, SS, RJSK, PS, PP, KC and SA acknowledges CSIR, and SO acknowledges Dept. of Biotechnology (DBT) India for their fellowship grants. Valuable suggestions and feedback provided by Dr. V.S.S. Prasad for preparing this manuscript is duly acknowledged. Authors would also like to thank the Director, National Chemical Laboratory Pune, India.

\section{References}

Axegard, P.; Jacobson, B.; Ljunggren, S. \& Nilvebrant, N.O. (1992). Bleaching of kraft pulps A research perspective. Papier, 46, V16-V25. ISSN 0031-1340 
Bate, N. J.; Orr, J.; Ni, W.; Meromi, A.; Nadler-Hassar, T.; Doerner, P. W.; Dixon, R.A.; Lamb, C. J. \& Elkind, Y. (1994). Quantitative relationship between phenylalanine ammonia-lyase levels and phenylpropanoid accumulation in transgenic tobacco identifies a ratedetermining step in natural product synthesis. Proceedings of the National Academy of Sciences USA, 91, 7608-7612. ISSN 00278424

Baucher, M.; Bernard-Vailhe, M. A.; Chabbert, B.; Besle, J. M.; Opsomer, C.; Van Montagu, M. \& Botterman, J. (1999). Downregulation of cinnamyl alcohol dehydrogenase in transgenic alfalfa (Medicago sativa L.) and the effect on lignin composition and digestibility. Plant Molecular Biology, 39, 437-447. ISSN 1573-5028

Baucher, M.; Halpin, C.; Petit-Conil, M. \& Boerjan W. (2003). Lignin: Genetic engineering and impact on pulping. Critical Reviews in Biochemistry and Molecular Biology, 38, 305-350. ISSN 1549-7798

Bierman, C.J. (1993). Essentials of Pulping and Papermaking. Academic Press, San Diego.

Biermann, C. J. (1996). Handbook of Pulping and Papermaking, (Ed.), Academic Press, San Diego, CA. ISSN 0091-679X

Bell-Lelong, D. A.; Cusumano, J. C.; Meye, K. \& Chapple, C. (1997). Cinnamate-4hydroxylase expression in Arabidopsis. Plant Physiology, 113, 729-738. ISSN 15322548

Blee, K. A.; Choi, J.W.; O'Connell, A.P.; Schuch, W.; Lewis, N. G. \& Bolwell, G.P. (2003). A lignin-specific peroxidase in tobacco whose antisense suppression leads to vascular tissue modification. Phytochemistry, 64, 163-176. ISSN 0031-9422

Boerjan, W.; Ralph, J. \& Baucher, M. (2003). Lignin Biosynthesis. Annual Review of Plant Biology, 54, 519-546. ISSN 1040-2519

Boerjan, W. (2005). Biotechnology and the domestication of forest trees. Current Opinion in Biotechnology, 16, 159-166. ISSN 0958-1669

Bomati, E. K. \& Noel, J. P. (2005).Structural and kinetic basis for substrate selectivity in Populus tremuloides sinapyl alcohol dehydrogenase. Plant Cell, 17, 1598-1611. ISSN 1532-298X

Boniwell, J. M. \& Butt, V. S. (1986). Flavin nucleotide-dependent 3-hydroxylation of 4hydroxyphenylpropanoid carboxylic acids by particulate preparations from potato tubers. Zeitschrift für Naturforschung, 41, 56-60. ISSN 0939-5075

Brownleader, M. D.; Ahmed, N.; Trevan, M.; Chaplin, M. F. \& Dey, P. M. (1995). Purification and partial characterization of tomato extensin peroxidase. Plant Physiology, 109, 1115-1123. ISSN 1532-2548

Campbell, M. M. \& Sederoff, R. R. (1996). Variation in lignin content and composition.Mechanisms of control and implications for the genetic improvement of plants. Plant Physiology, 110, 3-13. ISSN 1532-2548

Chabannes, M.; Ruel, K.; Yoshinaga, A; Chabbert, B.; Jauneau, A.; Joseleau, J. P. \& Boudet, A. M. (2001). In situ analysis of lignins in transgenic tobacco reveals a differential impact of individual transformations on the spatial patterns of lignin deposition at the cellular and subcellular levels. Plant Journal, 28, 271-82. ISSN 1365-313X

Chen, C.; Meyermans, H.; Burggraeve, B.; De Rycke, R. M.; Inoue, K.; Vleesschauwer, V. D.; Steenackers, M.; Van Montagu, M. C.; Engler, G. J. \& Boerjan, W. A. (2000). Cellspecific and conditional expression of caffeoyl-coenzyme A-3-O-methyltransferase in poplar. Plant Physiology, 123, 853-867. ISSN 1532-2548 
Chen, L.; Auh, C. K.; Dowling, P.; Bell, J.; Chen, F.; Hopkins, A.; Dixon, R.A. \& Wang, Z. Y. (2003) .Improved forage digestibility of tall fescue (Festuca arundinacea) by transgenic down-regulation of cinnamyl alcohol dehydrogenase. Plant Biotechnology Journal., 1, 437-449. ISSN 1863-5466

Chen, F.; Reddy, S.; M, S.; Temple, S.; Jackson, L.; Shadle, G. \& Dixon, R.A. (2006). Multi-site genetic modulation of monolignol biosynthesis suggests new routes for formation of Syringyl lignin and wall-bound ferulic acid in alfalfa (Medicago sativa L.). Plant Journal, 48, 113-124. ISSN 1365-313X

Chen, F. \& Dixon, R. A.(2007).Lignin modification improves fermentable sugar yields for biofuel production. Nature Biotechnology, 25, 759-761. ISSN 0733-222X

Chiang, V. L.; Puumala, R. J.; Takeuchi, H. \& Eckert, R. E.( 1988). Comparison of softwood and hardwood kraft pulping. Tappi Journals , 71, 173-176. ISSN 0734-1415

Christensen, J. H.; Baucher, M.; O'Connell, A. P.; Van Montagu, M. \& Boerjan, W. (2000). Control of lignin biosynthesis. Molecular Biology of Woody Plants, Vol.1, (Ed.), No. 64, 227-67. ISBN 978-0-7923-6241-8

Christensen, J. H.; Van Montagu, M; Bauw, G. \& Boerjan, W. (2001). Xylem peroxidases: purification and altered expression. Molecular Breeding of Woody Plants, Vol.18, 171176. ISBN 10- 0-444-50958-5

Croteau, R.; Kutchan, T. M. \& Lewis, NG. (2000) Natural products. Biochemistry and Molecular Biology of Plants, 1250-1318. ISBN 0943088372

Davison, B. H.; Drescher, S. R.; Tuskan, G. A.; Davis, M. F. \& Nghiem, N. P. (2006) .Variation of $\mathrm{S} / \mathrm{G}$ ratio and lignin content in a Populus family influences the release of xylose by dilute acid hydrolysis. Applied Biochemistry Biotechnolony 129-132, 427-435. ISSN 1559-0291

Day, A.; Neutelings, G.; Nolin,F.; Grec, S.; Habrant, A.; Crônier, D.; Maher, B.; Rolando, C.; David, H.; Chabbert, B. \& Hawkins, S.(2009). Caffeoyl coenzyme A Omethyltransferase down-regulation is associated with modifications in lignin and cell-wall architecture in flax secondary xylem. Plant Physiology and Biochemistry, 47, 9-19. ISSN 0981-9428

Escamilla-Trevino, L. L. \& Shen, H. (2010). Switchgrass (Panicum virgatum) possesses a divergent family of cinnamoyl CoA reductases with distinct biochemical properties. New Phytologist, 185(1), 143-155. ISSN 1469-8137

Franke, R.; Humphreys, J. M.; Hemm, M. R.; Denault, J. W.; Ruegger, M. O.; Cusumano, J. C. \& Chapple, C. (2002) .The Arabidopsis REF8 gene encodes the 3-hydroxylase of phenylpropanoid metabolism. Plant Journal, 30, 33-45. ISSN 1365-313X

Freudenberg, K. \& Neish, A. C. (1968). Constitution and Biosynthesis of Lignin. SpringerVerlag, pp129. ISSN 1095-9203

Goujon, T.; Sibout, R.; Pollet, B.; Maba, B.; Nussaume, L.; Bechtold, N.; Lu, F.; Ralph, J.; Mila, I.; Barri ere,Y.; Lapierre, C., \& Jouanin, L. (2003a). A new Arabidopsis thaliana mutant deficient in the expression of O-methyltransferase impacts lignins and sinapoyl esters. Plant Molecular Biology, 51, 973-989. ISSN 1573-5028

Goujon, T.; Ferret, V.; Mila, I.; Pollet, B.; Ruel, K.; Burlat, V.; Joseleau, J. P.; Barriere, Y.; Lapierre, C. \& Jouanin, L. (2003b). Down-regulation of the AtCCR1 gene in Arabidopsis thaliana: effects on phenotype, lignins and cell wall degradability. Planta, 217,218-228. ISSN 1432-2048 
Goyal, Y.; Bingham, R. L. \& Felker, P. (1985). Propagation of the tropical tree, L. leucocephala K67, by in vitro bud culture. Plant Cell, Tissue and Organ Culture, 4, 3-10.ISSN 15735044

Grand, C.; B, A. \& Boudet, A. M. (1983). Isoenzymes of hydroxycinnamate: CoA ligasefrom poplar stems: properties and tissue distribution. Planta, 158, 225-229. ISSN: 14322048

Gross, G. (1985). Biosynthesis and metabolism of phenolic acids and monolignols. In Biosynthesis and Biodegradation of Wood Components. Higuchi, T. (ed), Academic Press, New York, 229-271. ISSN 0003-2697

Guo, D.; Chen, F.; Inoue, K.; Blount, J. W. \& Dixon, R. A. (2001a). Downregulation of caffeic acid 3-O-methyltransferase and caffeoyl CoA 3-O-methyltransferase in transgenic alfalfa. impacts on lignin structure and implications for the biosynthesis of $\mathrm{G}$ and $\mathrm{S}$ lignin. Plant Cell, 13, 73-88. ISSN 1532-298X

Guo, D.; Chen, F.; Wheeler, J.; Winder, J.; Selman, S.; Peterson, M. \& Dixon, R. A. (2001b). Improvement of in-rumen digestibility of alfalfa forage by genetic manipulation of lignin O-methyltransferases. Transgenic Research, 10, 457-464. ISSN 1573-9368

Halpin, C.; Knight, M. E.; Foxon, G. A.; Campbell, M. M.; Boudet, A. M.; Boon, J. J.; Chabbert, B.; Tollier, M. T. \& Schuch, W. (1994). Manipulation of lignin quality by downregulation of Cinnamyl alcohol dehydrogenase. Plant Journal., 6, 339-350. ISSN 1365-313X

Hammond, A. C.; Allison, M. J. \& Williams, M. J. (1989). Persistence of DHP-degrading bacteria between growing seasons in subtropical Florida. Leucaena Research Report, 10, 66. ISSN 0254-8364

Harding, S. A.; Leshkevich, J.; Chiang, V. L. \& Tsai, C. J. (2002). Differential substrate inhibition couples kinetically distinct 4-coumarate:coenzyme A ligases with spatially distinct metabolic roles in quaking aspen. Plant Physiology, 128, 428438.ISSN 1532-2548

Hatton, D.; Sablowski, R.; Yung, M. H.; Smith, C.; Schuch, W. \& Bevan, M. (1995). Two classes of cis sequences contribute to tissue-specific expression of a PAL2 promoter in transgenic tobacco. Plant Journal, 7, 859-876. ISSN 1365-313X

He, X.; Hall, M. B.; Gallo-Meagher, M. \& Smith, R. L. (2003).Improvement of forage quality by downregulation of maize O-methyltransferase. Crop Science, 43, 2240-2251. ISSN 0011-183X

Hegarty, M. P.; Court, R. D. \& Thorne, P. M. (1964) .The determination of mimosine and 3, 4DHP in biological material. Australia Journal of Agricultural Research, 15, 168. ISSN 0004-9409

Higuchi, T. (1985). Biosynthesis of lignin. In: Higuchi, T. (ed.), Biosynthesis and biodegradation of wood components. Academic Press, New York, 141-160.

Higuchi, T. (1990). Lignin biochemistry: biosynthesis and biodegradation. Wood Science Technology, 24, 23-63. ISSN 1432-5225

Hinman, R. L. \& Lang, J. (1965) Peroxidase catalyzed oxidation of indole3acetic acid. Biochemistry, 4, 144-158 ISSN 1532-2548

Hoffmann, L.; Maur, S.; Martz, F.; Geoffre, P. \& Legrand, M. (2002). Purification, cloning and properties of an acyltransferase controlling shikimate and quinate ester intermediates in phenylpropanoid metabolism. J. Biological Chemistry, 278, 95-103. ISSN 1083-351X 
Hoffmann, L .; Besseau, S.; Geoffroy, P.; Ritzenthaler, C.; Meyer, D.; Lapierre, C.; Pollet, B. \& Legrand, M. (2004). Silencing of hydroxycinnamoyl-coenzyme A shikimate/quinate hydroxycinnamoyltransferase affects phenylpropanoid biosynthesis. The Plant Cell, 16, 1446-1465. ISSN 1532-298X

Hoffmann, L.; Besseau, S.; Geoffroy, P.; Meyer, D.; Lapierre, C.; Pollet, B. \& Legrand, M.(2007). Flavonoid accumulation in Arabidopsis repressed in lignin synthesis affects auxin transport and plant growth. The Plant Cell, 19, 148-162. ISSN 1532298X

Hu, W. J.; Kawaoka, A.; Tsai, C. J.; Lung, J.; Osakabe, K.; Ebinuma, H. \& Chiang, V. L. (1998). Compartmentalized expression of two structurally and functionally distinct 4coumarate:CoA ligase genes in aspen (Populus tremuloides). Proceedings of the National Academy of Science, 95, 5407- 5412. ISSN 0027-8424

Hu, W. J.; Harding, S. A.; Lung, J.; Popko, J. L.; Ralph, J.; Stokke, D. D.; Tsai, C. J. \& Chiang, V. L. (1999). Repression of lignin biosynthesis promotes cellulose accumulation and growth in transgenic trees. Nature Biotechnology, 17, 808-812. ISSN 0733-222X

Humphreys, J. M.; H, M. \& Chapple, C. (1999). New routes for lignin biosynthesis defined by biochemical characterization of recombinant ferulate 5-hydroxylase, a multifunctional cytochrome P450-dependent monooxygenase. Proceedings of theNational Academy of Science (USA), 96, 10045-10050. ISSN 0027-8424

Humphreys, J. M. \& Chapple, C.(2002). Rewriting the lignin roadmap. Current Opinion in Plant Biology, 5, 224-229. ISSN 1369-5266

Hussain, T. M.; Thummala, C. \& Ghanta, R. G. (2007). High frequency shoots regeneration of Stercula urens Roxb. an endangered tree species through cotyledonary node cultures. African Journal of Biotechnology, 6(15), 1643-1649. ISSN 1684-5315

Jones, H. D. (1984) .Phenylalanine ammonia-lyase: Regulation of its induction, and its role in plant development. Phytochemistry, 23, 1349-1359. ISSN 0031-9422

Jones, L.; Ennos, A. R. \& Turner, S. R. (2001). Cloning and characterization of irregular xylem4 (irx4): a severely lignin deficient mutant of Arabidopsis. Plant Journal, 26, 205-216. ISSN 1365-313X

Jones, R. J. (1979). The value of Leucaena leucocephala as feed for ruminants in the tropics. World Animal review, 32, 10. ISBN 92-5-100650-4

Jouanin, L.; Goujon, T.; Nadai, V. D.; Martin, M. T.; Mila, I.; Vallet, C.; Pollet, B.; Yoshinaga, A.; Chabbert, B.; Conil, M. P. \& Lapierre, C. (2000). Lignification in transgenic poplars with extremely reduced caffeic acid $\mathrm{O}$ methyltransferase activity. Plant Physiology., 123, 1363-1374. ISSN 1532-2548

Kao, Y. Y.; Harding, S. A. \& Tsai, C. J. (2002). Differential expression of two distinct phenylalanine ammonia-lyase genes in condensed tannin-accumulating and lignifying cells of quaking aspen. Plant Physiology, 130, 796-807. ISSN 1532-2548

Kavousi, B.; Daudi, A.; Cook, C. M.; Joseleau, J. P.; Ruel, K.; Devoto, A.; Bolwell, G. P. \& Blee, K. A.(2010). Consequences of antisense down-regulation of a lignificationspecific peroxidase on leaf and vascular tissue in tobacco lines demonstrating enhanced enzymic saccharification. Phytochemistry, 71, 531-542. ISSN $0031-9422$

Kojima, M. \& Takeuchi, W. (1989). Detection and characterization of p-coumaric acid hydroxylase in mung bean, Vigna mungo, seedlings. Biochemical Journal, 105, $265-$ 270. ISSN 1470-8728 
Kumar, A. \& Ellis, BE. (2001). The phenylalanine ammonia-lyase gene family in raspberry. Structure, expression, and evolution. Plant Physiology, 127, 230- 239. ISSN 1532-2548

Lacombe, E. \& Hawkins, S. (1997). Cinnamoyl CoA reductase, the first committed enzyme of the lignin branch biosynthetic pathway: cloning, expression and phylogenetic relationships. Plant Journal, 11(3), 429-441. ISSN 1365-313X

Lapierre, C.; Pilate, G.; Pollet, B.; Mila, I.; Leple, J.C.; Jouanin, L.; Kim, H. \& Ralph, J. (2004). Signatures of cinnamyl alcohol dehydrogenase deficiency in poplar lignins. Phytochemistry, 65, 313-321. ISSN 0031-9422

Larsen, K. (2004). Molecular cloning and characterization of cDNAs encoding cinnamoyl CoA reductase (CCR) from barley (Hordeum vulgare) and potato (Solanum tuberosum). Journal of Plant Physiology, 161(1), 105-12. ISSN 1532-2548

Lauvergeat, V. \& Lacomme, C. et al. (2001). Two cinnamoyl-CoA reductase (CCR) genes from Arabidopsis thaliana are differentially expressed during development and in response to infection with pathogenic bacteria. Phytochemistry, 57(7), 1187-1195. ISSN 0031-9422

Lee, D.; Meyer, K.; Chapple, C. \& Douglas, C. J. (1997). Antisense suppression of 4coumarate: coenzyme A ligase activity in Arabidopsis leads to altered lignin subunit composition. Plant Cell, 9, 985- 998. ISSN 1532-298X

Leple, J. C. \& Dauwe, R. et al. (2007). Downregulation of cinnamoyl-coenzyme A reductase in poplar: multiple-level phenotyping reveals effects on cell wall polymer metabolism and structure. Plant Cell, 19(11), 3669-3691. ISSN 1532-298X

Lewis, N. G. \& Yamamoto, E. (1990) Lignin: Occurrence, biogenesis, and biodegradation. Annual Review Plant Physiology and Plant Molecular Biology, 41, 455-496. ISSN 10402519

Leyva, A.; Liang, X.; Pintor-Toro, J. A.; Dixon, R. A. \& Lamb, C. J. (1992). cis-Element combinations determine phenylalanine ammonia-lyase gene tissue specific expression patterns. Plant Cell, 4, 263-271. ISSN 1532-298X

Li, L.; Popko, J. L.; Umezawa, T. \& Chiang, V. L. (2000). 5-Hydroxyconiferyl aldehyde modulates enzymatic methylation for syringyl monolignol formation, a new view of monolignol biosynthesis in angiosperms. Journal of Biological Chemistry, 275, 6537-6545. ISSN 1083-351X

Li, L.; Cheng, X. F.; Leshkevich, J.; Umezawa, T.; Harding, S. A. \& Chiang, V. L. (2001). The last step of syringyl monolignol biosynthesis in angiosperms is regulated by a novel gene encoding sinapyl alcohol dehydrogenase. Plant Cell, 13, 1567-1585. ISSN 1532-298X

Li, L. \& Cheng, X. et al. (2005). Clarification of cinnamoyl co-enzyme A reductase catalysis in monolignol biosynthesis of Aspen. Plant Cell Physiology, 46(7), 1073-1082. ISSN 1471-9053

Li, X.; Weng, J. K. \& Chapple, C. (2010). The Growth Reduction Associated with Repressed Lignin Biosynthesis in Arabidopsis thaliana Is Independent of Flavonoids. The Plant Cell, 22, 1620-1632. ISSN 1532-298X

Lindermayr, C.; Fliegmann, J. \& Ebel, J. (2003). Deletion of a single amino acid residue from different 4-coumarate-CoA ligases from soybean results in the generation of new substrate specificities. Journal of Biological Chemistry, 278, 2781-2786. ISSN 1083$351 X$ 
Logemann, E.; Parniske, M. \& Hahlbrock, K. (1995). Modes of expression and common structural features of the complete phenylalanine ammonia-lyase gene family in parsley. Proceedings of the National Academy of Science USA, 92, 5905-5909. ISSN 0027-8424

Ma, Q. H. \& Tian, B. (2005). Biochemical characterization of a cinnamoyl-CoA reductase from wheat. Journal of Biological Chemistry, 386(6), 553-560. ISSN 1083-351X

Ma, Q. H. (2007). Characterization of a cinnamoyl-CoA reductase that is associated with stem development in wheat. Journal of Experimental Botany, 58(8), 2011-2021. ISSN 0022-0957

Marita, J. M.; Vermerris, W.; Ralph, J. \& Hatfield, R.D. (2003) Variations in the cell wall composition of maize brown midrib mutants. Journal of Agricultural and Food Chemistry, 51, 1313-1321. ISSN 0021-8561

Marjamaa, K.; Hildén, K.; Kukkola, E.; Lehtonen, M.; Holkeri, H.; Haapaniemi, P.; Koutaniemi, S.; Teeri, T. H.; Fagerstedt, K. \& Lundell, T.(2006). Cloning, characterization and localization of three novel class III peroxidases in lignifying xylem of Norway spruce (Picea abies). Plant Molecular Biology, 61, 719-732. ISSN 0167-4412

Martz, F.; Maury, S.; Pincon, G. \& Legrand, M. (1998). cDNA cloning, substrate specificity and expression study of tobacco caffeoyl-CoA 3-O-methyltransferase, a lignin biosynthetic enzyme. Plant Molecular Biology, 36, 427-437. ISSN 0167-4412

McInnes, R. \& Lidgett, A. et al. (2002). Isolation and characterization of a cinnamoyl-CoA reductase gene from perennial ryegrass (Lolium perenne). Journal of Plant Physiology, 159(4), 415-422. ISSN 0176-1617

Merkle, S. \& Nairn, J. (2005). Hardwood tree biotechnology. In Vitro Cellular \& Developmental Biology - Plant, 41, 602-619. ISSN 1054-5476

Mizutani, M.; Ohta, S. \& Sato, R. (1997). Isolation of a cDNA and a genomic clone encoding cinnamate 4-hydroxylase from Arabidopsis and its expression manner in planta. Plant Physiology, 113, 755-763.ISSN 0032-0889

Moore, K. J. \& Jung, H. G. (2001). Lignin and fiber digestion. Journal of Range Management, 54, 420-430. ISSN 0022-409X

Nair, R. B.; Xia, Q.; Kartha, C. J.; Kurylo, E.; Hirji, R. N.; Datla, R. \& Selvaraj, G. (2002). Arabidopsis CYP98A3 mediating aromatic 3-hydroxylation. Developmental regulation of the gene, and expression in yeast. Plant Physiology, 130, 210-20. ISSN 0032-0889

Nieminen, K. M.; Kauppinen, L. \& Helariutta, Y. (2004). A weed for wood? Arabidopsis as a genetic model for xylem development. Plant Physiology, 135, 653-659. ISSN 00320889

O'Connell, A., Holt, K., Piquemal, J., Grima-Pettenati, J., Boudet, A., Pollet, B., Lapierre, C., Petit-Conil, M., Schuch, W. and Halpin, C. (2002). Improved paper pulp from plants with suppressed cinnamoyl- CoA reductase or cinnamyl alcohol dehydrogenase. Transgenic Research, 11, 495-503. ISSN 0962-8819

Odendahl, S. (1994). Environmental protection and consumer demands: a review of trends and impacts. Pulp \& Paper Canada, 95, 144-148. ISSN 0316-4004

Ohl, S.; Hedrick, S. A.; Chory, J. \& Lamb, C. J. (1990). Functional properties of a phenylalanine ammonia lyase promoter from Arabidopsis. Plant Cell, 2, 837-848. ISSN 1040-4651 
Osakabe, Y.; Ohtsubo, Y.; Kawai, S.; Katayama, Y. \& Morohoshi, N. (1995). Structures and tissue specific expression of genes for phenylalanine ammonialyase from a hybrid aspen. Plant Science, 105, 217-226.ISSN 0168-9452

Osakabe, K.; Tsao C.; Li, L.; Popko, J. L.; Umezawa, T.; Carraway, D. T.; Smeltzer, R. H.; Joshi, C. P. \& Chiang, V. L. (1999). Coniferyl aldehyde 5-hydroxylation and methylation direct syringyl lignin biosynthesis in angiosperms. Proceedings of the Natlional Academy of Science (USA), 96, 8955-8960. ISSN 0027-8424

Pakusch, A. E.; Kneusel, R. E. \& Matern, U. (1989) S-Adenosyl-lmethionine: trans-caffeoylcoenzyme A 3-O-methyltransferase from elicitor-treated parsley cell suspension cultures. Archives of Biochemistry and Biophysics 271: 488-494. ISSN 0003-9861

Petersen, M.; Strack, D. \& Matern, U. (1999) .Biosynthesis of phenylpropanoids and related compounds. In: Biochemistry of Plant Secondary Metabolism. Wink, M. (Ed.), Vol. 2, pp 151-222, Sheffield Academic Press, Sheffield, UK. ISSN 0309-0787

Petit-Conil, M.; Lapierre, C.; Pollet, B.; Mila, I.; Meyermans, H.; Pilate, G.; Leple, J. C.; Jouanin, L.; Boerjan, W. \& de Choudens, C. (1999). Impact of lignin engineering on pulping processes of poplar trees. In Proceedings of the 27th EUCEPA Conference. Paris: ATIP Press, pp. 1-10.

Pichon, M. \& Courbou, I. et al. (1998). Cloning and characterization of two maize cDNAs encoding cinnamoyl-CoA reductase (CCR) and differential expression of the corresponding genes. Plant Molecular Biology, 38(4), 671-676. ISSN 1573-5028

Piquemal, J. Lapierre, C.; Myton, K.; O'Connell, A.; Schuch, W.; Grima-Pettenati, J. \& Boudet A.M. (1998). Down-regulation of cinnamoyl-CoA reductase induces significant changes of lignin profiles in transgenic tobacco plants. Plant Journal, 13(1), 71-83. ISSN 1365-313X

Prasad, JVNS.; Korwar, G. R.; Rao, K. V.; Mandal, U. K.; Rao, G. R.; Srinivas, I.; Venkateswarlu, B.; Rao, S. N. \& Kulkarni, H. D. (2010). Optimum stand density of Leucaena leucocephala for wood production in Andhra Pradesh, Southern India. Biomass Bioenergy, 348, 1-9. ISSN 0961-9534

Quiroga, M.; Guerrero, C.; Botella, M. A.; Barcelo, A.; Amaya, I.; Medina, M. I.; Alonso, F. J.; Forchetti, S. M.; Tigier, H. \& Valpuesta, V. (2000). A tomato peroxidase involved in the synthesis of lignin and suberin. Plant Physiology, 122, 1119-1127. ISSN 1532-2548

Raes, J.; Rohde,A.; Christensen, J. H.; Peer,Y. V. \& Boerjan, W. (2003). Genome-wide characterization of the lignification toolbox in Arabidopsis. Plant Physiology, 133, 1051-1071. ISSN 1532-2548

Ralph, J.; Hatfield, R. D.; Piquemal, J.; Yahiaoui, N.; Pean, M.; Lapierre, C. \& Boudet, A. M. (1998). NMR characterization of altered lignins extracted from tobacco plants down-regulated for lignification enzymes cinnamyl alcohol dehydrogenase and cinnamoyl CoA reductase. Proceedings of the National Academy of Sciences, 95, 1280312808. ISSN 0027-8424

Rastogi, S. \& Dwivedi, U. N. (2003a). Agrobacterium tumefaciens mediated transformation of Leucaena leucocephalas multipurpose tree legume. Physiology and Molecular Biology of Plants, 9, 207-216. ISSN 0974-0430

Rastogi, S.; Rizvi, S. M. H.; Singh, R. P. \& Dwivedi, U.N. (2008). In vitro regeneration of Leucaena leucocephala by organogenesis and somatic embryogenesis. Biologia Plantarum, 52, 743-748. ISSN 1573-8264 
Reddy, M. S.; Chen, F.; Shadle, G.; Jackson, L.; Aljoe, H. \& Dixon, R. A. (2005). Targeted down-regulation of cytochrome P450 enzymes for forage quality improvement in alfalfa (Medicago sativa L.). Proceedings of the National Academy of Sciences USA, 102, 16573-16578. ISSN 0027-8424

Rogers, L. A. \& Campbell, M. M.(2004). The genetic control of lignin deposition during plant growth and development. New Phytologist, 164, 17-30. ISSN 1469-8137

Saafi, H. \& Borthakur, D. (2002). In vitro plantlet regeneration from cotyledons of the tree legume of Leucaena leucocephala. Plant Growth Regulation, 38, 279-285. 1573-5087

Sarkanen, K. V. \& Ludwig, C. H. (1971). Lignins: Occurrence, Formation, Structure, and Reactions. New York: Wiley-Interscience, pp 916. ISBN 0-471-75422-6

Sato, Y.; Sugiyama, M.; Gorecki, R. J.; Fukuda, H. \& Komamine, A. (1993). Interrelationship between lignin deposition and the activities of peroxidase isoenzymes in differentiating tracheary elements of Zinnia. Analysis using La- aminoxy- $\beta$ phenylpropionic acid and 2aminoindan2phosphonic acid. Planta, 189, 584589. ISSN 1432-2048

Schoch, G.; Goepfert, S.; Morant, M.; Hehn, A.; Meyer, D.; Ullmann, P. \& Werck-Reichhart, D. (2001). CYP98A3 from Arabidopsis thaliana is a 3 -hydroxylase of phenolic esters, a missing link in the phenylpropanoid pathway. Journal of Biological Chemistry, 276, 36566-36574. ISSN 1083-351X

Sewalt, V.; Ni, W.; Blount, J. W.; Jung, H. G.; Masoud, S. A.; Howles, P. A.; Lamb, C. \& Dixon, R. A. (1997a) .Reduced lignin content and altered lignin composition in transgenic tobacco down-regulated in expression of L-phenylalanine ammonialyase or cinnamate 4-hydroxylase. Plant Physiology, 115, 41-50. ISSN 1532-2548

Sewalt, V.J.H.; Ni, W. T.; Jung, H. G. \& Dixon, R. A. (1997b). Lignin impact on fiber degradation: increased enzymatic digestibility of genetically engineered tobacco (Nicotiana tabacum) stems reduced in lignin content. Journal of Agricultural and Food Chemistry, 45, 1977-1983. ISSN 0021-8561

Shadle, G.; Chen, F.; Srinivasa Reddy, M. S.; Jackson, L.; Nakashima, J. \& Dixon, R. A. (2007). Down-regulation of hydroxycinnamoyl CoA:shikimate hydroxycinnamoyl transferase in transgenic alfalfa affects lignification, development and forage quality. Phytochemistry, 68, 1521-1529.

Shaik, N. M.; Arha, M.; Nookaraju, A.; Gupta, S. K.; Srivastava, S.; Yadav, A. K., Kulkarni, P. S.; Abhilash, O. U.; Vishwakarma, R. K.; Singh, S.; Tatkare, R.; Chinnathambi, K.; Rawal, S. K. \& Khan, B. M. (2009). Improved method of in vitro regeneration in Leucaena leucocephala - a leguminous pulpwood tree species. Physiology and Molecular Biology of Plants, 15(4), 311-318. ISSN 0971-5894

Shanfa, L.; Yohua, Z.; Laigeng, L. \& Vincent, L. C. (2006). Distinct Roles of Cinnamate 4hydroxylase Genes in Populus. Plant Cell Physilogy, 47(7),905-914. ISSN 0032-0781

Sirisha,V. L.; Prashant, S.; Ranadheer, D.; Ramprasad, P.; Shaik, N. M.; Arha, M.; Gupta, S. K.; Srivastava, S.; Yadav, A. K.; Kulkarni, P. S.; Abhilash, O. U.; Khan, B. M.; Rawal, S. K. \& Kavi Kishor, P. B. (2008). Direct shoot organogenesis and plant regeneration from hypocotyl explants in selected genotypes of Leucaena leucocephala-A leguminous pulpwood tree. Indian Journal of Biotechnology, 7, 388-93. ISSN 09725849

Srivastava, S.; Gupta, R.; Arha, M.; Vishwakarma, R.K.; Rawal, S.K.; Kavi Kishor, P.B. \& Khan, B.M. (2011). Expression analysis of cinnamoyl-CoA reductase (CCR) gene in 
developing seedlings of Leucaena leucocephala: A pulp yielding tree species. Plant Physiology and Biochemistry, 49,138-145. ISSN 0981-9428

Stafford, H. A. \& Dresler, S. (1972). 4-Hydroxycinnamic acid hydroxylase and polyphenolase activities in Sorghum vulgare. Plant Physiology, 49, 590-595. ISSN 1532-2548

Steeves, C.; F“orster, H.; Pommer, U. \& Savidge, R. (2001). Coniferyl alcohol metabolism in conifers. I. Glucosidic turnover of cinnamyl aldehydes by UDPG: coniferyl alcohol glucosyltransferase from pine cambium. Phytochemistry ,57,1085-93. ISSN 0031-9422

Strauss, S. H.; Rottmann, W. H.; Brunner, A. M. \& Sheppard, L.A. (1995) Genetic engineering of reproductive sterility in forest trees. Molecular Breeding, 1, 5-26. ISSN 1380-3743

Talas-Ogras, T.; Kazan, K. \& Gözükirmizi, N. (2001). Decreased peroxidase activity in,transgenic tobacco and its effect on lignification. Biotechnology Letter , 23, 267-273. ISSN 0141-5492

Vailhe, M.A.B.; Besle, J. M.; Maillot, M. P.; Cornu, A.; Halpin, C. \& Knight, M. (1998). Effect of down-regulation of cinnamyl alcohol dehydrogenase on cell wall composition and on degradability of tobacco stems. Journal of the Science of Food and Agriculture, 76, 505-514. ISSN 0022-5142

Vietmeyer, N. \& Cottom, B. (1977). In Leucaena: Promising Forage and Tree Crop for the Tropics. Ruskin, F. R. (Ed.), Proceedings of the National Academy of Sciences, Washington, DC, 22-80. ISSN 0027-8424

Voelker, S. L.; Lachenbruch, B.; Meinzer, F. C.; Jourdes, M.; Ki, C.; Patten, A. M.; Davin, L. B.; Lewis, N. G.; Tuskan, G. A.; Gunter, L.; Decker, S. R.; Selig, M.; Sykes, R.; Himmel, M. E.; Kitin, P.; Shevchenko, O. \& Strauss, S. H. (2010). Antisense downregulation of $4 \mathrm{CL}$ expression alters lignification, tree growth, and saccharification potential of field-grown poplar. Plant Physiology, 154, 874-886. ISSN 1532-2548

Voo, K. S.; Whetten, R. W.; O'Malley, D. M. \& Sederoff, R. R. (1995) 4-coumarate:coenzyme a ligase from loblolly pine xylem. Isolation, characterization, and complementary DNA cloning. Plant Physiology, 108, 85-97. ISSN 1532-2548

Wadenback, J.; von Arnold, S.; Egertsdotter, U.; Walter, M. H.; Grima-Pettenati, J.; Goffner, D.; Gellerstedt, G.; Gullion, T. \& Clapham, D. (2007). Lignin biosynthesis in transgenic Norway spruce plants harboring an antisense construct for Cinnamoyl CoA reductase (CCR). Transgenic Research, 17(3), 379-92. ISSN 0962-8819

Whetten, R. \& Sederoff, R. (1995). Lignin biosynthesis. Plant Cell, 7, 1001-1013. ISSN 1532298X

Whetten, R. W.; MacKay, J. J. \& Sederoff, R. R. (1998). Recent advances in understanding lignin biosynthesis. Annual Review of Plant Physiology and Plant Molecular Biology, 49, 585-609. ISSN 1040-2519

Ye, Z. H.; Kneusel, R. E.; Matern, U. \& Varner, J. E. (1994). An alternative methylation pathway in lignin biosynthesis in Zinnia. Plant Cell, 6, 1427-1439. ISSN 1532-298X

Ye, Z. H. \& Varner, J. E. (1995). Differential expression of two O-methyltransferases in lignin biosynthesis in Zinnia elegans. Plant Physiology ,1084, 59-467. ISSN 1532-2548

Ye, Z. H. (1997). Association of caffeoyl coenzyme A 3-O-methyltransferase expression with lignifying tissues in several dicot plants. Plant Physiology, 115, 1341-1350. ISSN 1532-2548 
Zhong, R.; Demura, T. \& Ye, Z. H. (2006). SND1, a NAC domain transcription factor, is a key regulator of secondary wall synthesis in fibres of Arabidopsis. Plant Cell, 18, 31583170. ISSN 1532-298X

Zhong, R.; Lee, C.; Zhou, J.; McCarthy, R. L. \& Ye, Z. H. (2008). A battery of transcription factors involved in the regulation of secondary cell wall biosynthesis in Arabidopsis. Plant Cell, 20, 2763-2782. ISSN 1532-298X

Zhou, R. \& Jackson, L. et al. (2010). Distinct cinnamoyl CoA reductases involved in parallel routes to lignin in Medicago truncatula. Proceedings of the National Academy of Sciences U S A, 107(41), 17803-17808. ISSN 0027-8424

Zimmerlin, A.; Wojtaszek, P. \& Bolwell, G. P. (1994). Synthesis of dehydrogenation polymers of ferulic acid with high specificity by a purified cellwall peroxidase from French bean (Phaseolus vulgaris L.). Biochemical Journal, 299, 747-753. ISSN 1470-8728 


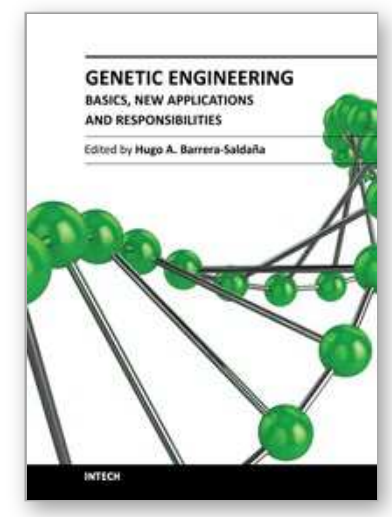

\author{
Genetic Engineering - Basics, New Applications and \\ Responsibilities \\ Edited by Prof. Hugo A. Barrera-Saldaña
}

ISBN 978-953-307-790-1

Hard cover, 256 pages

Publisher InTech

Published online 18, January, 2012

Published in print edition January, 2012

Leading scientists from different countries around the world contributed valuable essays on the basic applications and safety, as well as the ethical and moral considerations, of the powerful genetic engineering tools now available for modifying the molecules, pathways, and phenotypes of species of agricultural, industrial and even medical importance. After three decades of perfecting such tools, we now see a refined technology, surprisingly unexpected applications, and matured guidelines to avoid unintentional damage to our and other species, as well as the environment, while trying to contribute to solve the biological, medical and technical challenges of society and industry. Chapters on thermo-stabilization of luciferase, engineering of the phenylpropanoid pathway in a species of high demand for the paper industry, more efficient regeneration of transgenic soybean, viral resistant plants, and a novel approach for rapidly screening properties of newly discovered animal growth hormones, illustrate the state-of-the-art science and technology of genetic engineering, but also serve to raise public awareness of the pros and cons that this young scientific discipline has to offer to mankind.

\title{
How to reference
}

In order to correctly reference this scholarly work, feel free to copy and paste the following:

Bashir M. Khan, Shuban K. Rawal, Manish Arha, Sushim K. Gupta, Sameer Srivastava, Noor M. Shaik, Arun K. Yadav, Pallavi S. Kulkarni, O. U. Abhilash, SantoshKumar, Sumita Omer, Rishi K. Vishwakarma, Somesh Singh, R. J. Santosh Kumar, Prashant Sonawane, Parth Patel, C. Kannan, Shakeel Abbassi (2012). Genetic Engineering of Phenylpropanoid Pathway in Leucaena leucocephala, Genetic Engineering - Basics, New Applications and Responsibilities, Prof. Hugo A. Barrera-Saldaña (Ed.), ISBN: 978-953-307-790-1, InTech, Available from: http://www.intechopen.com/books/genetic-engineering-basics-new-applications-andresponsibilities/genetic-engineering-of-phenylpropanoid-pathway-in-leucaena-leucocephala

\section{INTECH}

open science | open minds

\section{InTech Europe}

University Campus STeP Ri

Slavka Krautzeka 83/A

51000 Rijeka, Croatia

Phone: +385 (51) 770447

Fax: +385 (51) 686166

\section{InTech China}

Unit 405, Office Block, Hotel Equatorial Shanghai

No.65, Yan An Road (West), Shanghai, 200040, China 中国上海市延安西路65号上海国际贵都大饭店办公楼 405 单元

Phone: +86-21-62489820

Fax: +86-21-62489821 
www.intechopen.com 
(C) 2012 The Author(s). Licensee IntechOpen. This is an open access article distributed under the terms of the Creative Commons Attribution 3.0 License, which permits unrestricted use, distribution, and reproduction in any medium, provided the original work is properly cited. 